CEP Discussion Paper No 826

October 2007

\title{
Information Technology, Organization, and Productivity in the Public Sector: Evidence from Police Departments \\ Luis Garicano and Paul Heaton
}




\begin{abstract}
We examine how information technology (IT) contributes to organizational change, labor demand, and improved productivity in the public sector using a new panel data set of police departments covering 1987-2003. While IT adoption is associated with increased administrative and organizational complexity and use of more highly educated officers, IT itself does not appear to enhance crimefighting effectiveness. These results are robust to various methods for controlling for agency-level characteristics and the endogeneity of IT use. IT investments do, however, appear to improve police productivity when complemented with particular management practices-in this case, those associated with the Compstat program.
\end{abstract}

Keywords: information technology, management practices, skills, productivity, police JEL Classification: L23, M5, O33, K42

This paper was produced as part of the Centre's Productivity and Innovation Programme. The Centre for Economic Performance is financed by the Economic and Social Research Council.

\title{
Acknowledgements
}

Garicano thanks the Toulouse Network for Information Technology (TNIT) and Heaton the National Consortium on Violence Research (NCOVR) for financial support. We also thank Daron Acemoglu, David Autor, Austan Goolsbee, Robert Topel, and Toulouse Network members for their comments. All opinions expressed in the paper are solely those of the authors and not the aforementioned organizations.

Luis Garicano is an Associate of the Productivity and Innovation Programme at the Centre for Economic Performance, London School of Economics. He is also Professor of Economics and Strategy, Graduate School of Business, University of Chicago and Research Fellow and Director with CEPR. Paul Heaton is an Associate Economist with the RAND Corporation. The authors can be reached at l.garicano@lse.ac.uk and pheaton@rand.org.

Published by

Centre for Economic Performance

London School of Economics and Political Science

Houghton Street

London WC2A 2AE

All rights reserved. No part of this publication may be reproduced, stored in a retrieval system or transmitted in any form or by any means without the prior permission in writing of the publisher nor be issued to the public or circulated in any form other than that in which it is published.

Requests for permission to reproduce any article or part of the Working Paper should be sent to the editor at the above address.

(C) L. Garicano and P. Heaton, submitted 2007

ISBN 9780853280873 


\section{Introduction}

Public sector organizations are important consumers of information technology (IT), primarily because many public functions such as revenue management, crime-fighting, and education are essentially information processing tasks. ${ }^{1}$ Thus, we might expect large changes in the cost of processing information to have an important impact on public organizations. Despite a growing literature on the effects of the spread of information technology (IT) on firms, there is little evidence regarding the extent to which IT is related to organization and productivity in the public sphere. In this paper we study the relationship between IT and the internal structure and effectiveness of public agencies using a newly constructed panel data set of police departments covering 1987-2003, which we have merged with FBI local-level crime data.

Our paper contributes to large bodies of research on the skill content of technological change and the impact of IT on the organization of work. Despite a growing literature, our knowledge of IT's role is still spotty, in part due to a paucity of firm-level data on organizational change, worker skill, and information technology adoption over time. Some previous studies of the impact of IT cannot examine organizational changes because they use the industry or a single firm as the unit of analysis [e.g. Stiroh (2002), Autor, Katz, and Krueger (1998), and Berman, Bound, and Griliches (1994), Aral, Brynjolfsson, and Alstyne (2007)], or because they rely on a cross-section of firms [e.g. Acemoglu, Aghion, Lelarge, Reenan, and Zilibotti (2006) and Bresnahan, Brynjolfsson, and Hitt $\left.(2002)^{2}\right]$. Others do follow individual firms over time, but either have no data on information technology adoption [e.g. Rajan and Wulf (2006), Berman, Bound, and Griliches (1994)], or no information on organizational change [e.g. Brynjolfsson and Hitt (2003)]. Only a very small number of previous papers provide firm-level evidence on the evolution of information technology, skill usage, and organizational

\footnotetext{
${ }^{1}$ Following Arrow (1974), a large literature studies organizations as information processing and problem solving institutions - e.g. Radner and Zandt (1992), Bolton and Dewatripont (1994), and Garicano (2000).

${ }^{2}$ This paper has panel data on IT and inputs, but cross-sectional information for organizational variables.
} 
change; notably Caroli and Reenen (2001), which reports data for the 1980s in the UK, and from the early 1990s for France, and Doms, Dunne, and Troske (1997), who study a panel of manufacturing firms between 1987 and 1992. Like these papers, our paper utilizes organizational-level data on the evolution of skills, organization, and information technology adoption. However, to our knowledge it is the first to systematically examine non-manufacturing firms - in our case, public organizations - and is unique in its coverage of almost half the firms and the majority of workers in the observed industry. Moreover, it is the only paper to include a long panel (16 years) covering most of the period of the recent IT revolution. Finally, by combining agency-level data on crime rates and arrest levels with our organizational data, we are able to incorporate rich productivity measures into our analysis.

We start by studying the relationship between computerization and productivity and organization using a panel of police departments. Our basic empirical strategy compares, controlling for city size and other characteristics, the organization and productivity of departments that adopted more computing technology to that of departments that adopted less. Consistent with previous research, ${ }^{3}$ we find that IT adoption and skill are complementary-departments that adopt IT increase police training and introduce college requirements for new recruits. This increase in training appears primarily related to the need to learn to use new devices, rather than IT-induced enhancement of the training process. Moreover, adopting departments become larger, increasingly employ special units, and include a larger fraction of support personnel. In sum, agencies become more highly skilled and their organization in many ways more complex. Despite these changes, we find little evidence that general IT adoption is associated by itself with an increase in the productivity of police work, as measured both by clearance rates and crime rates. We carefully analyze the generality of these results, and find them robust to alternative samples (by period, early adopters, growing versus non-growing cities, etc.) and specifications of the IT measure.

We next attempt to assess whether the associations between IT and organizational

\footnotetext{
${ }^{3}$ See, for example, Autor, Katz, and Krueger (1998) and Lehr and Lichtenberg (1999).
} 
change we document represent a causal effect of IT. Given the nature of organizational change, which often involves simultaneous adjustments on a number of dimensions and which may be driven by factors unobserved to researchers, sorting out causal pathways can be challenging. In particular, our findings suggesting that IT may promote organizational change could reflect reverse causality or omitted variable bias. Using the available data, we attempt to address several alternative explanations for the strong relationship between IT use and our organizational measures. By including both year and agency fixed effects in our specifications, we first remove variation that may be due to systematic differences across departments (such as geography) and macroeconomic trends. We also find our results robust to inclusion of time trends by state or initial level of computerization.

If, as agencies increase in size, their optimal structure involves increasing use of IT and changes in organizational form, failure to adequately account for agency size could suggest a spurious effect of IT on organization. In each of our baseline regressions we flexibly control for the relevant aspect of agency size or workload. As additional checks, we rerun our regressions first limiting the sample to the largest and smallest agencies and then including a full set of agency-size decile and year interactions as controls. The strong positive relationships between IT, worker training, and worker skill persist in these specifications.

Poorly managed departments may undergo overhauls that affect both IT use and organizational variables. Using civil litigation cases filed against an agency in 1987 as a measure of initial department quality, we uncover little evidence suggesting differential IT adoption by poorly functioning agencies. Alternatively, younger, dynamic cities, such as Houston or Seattle, may have unobserved characteristics that promote both IT use and different bureaucratic evolution. Limiting the sample to shrinking cities or cities with little population change does not alter our conclusions, however.

We also estimate specifications including leads of IT intensity as additional explanatory variables to assess whether exogenous organizational reform could prompt IT adoption (reverse causality), but obtain little indication of such effects. Another 
possibility is that agencies with larger budgets are able to implement both information technology and superior organizational practices such as increased training. However, the strong relationship between IT and organization persists when we directly control for equipment expenditure in our regressions, suggesting that this relationship is not driven primarily by resource availability.

We also study whether our findings reflect (previous) mismeasurement of crime: although some information technologies, such as those that identify crime 'hot-spots', should improve deterrence, others could actually worsen crime statistics. For example, if crime reporting is improved, reported crime rates will increase while clearance rates will drop. Our data contain detailed questions on computer functions, such as recordkeeping, police dispatch, fleet management, etc. We test for heterogenous effects of different technologies by simultaneously entering record-keeping and deployment measures in our panel regressions. We find that offense reports increase by $10 \%$ when computers are used for record keeping, and that these effects occur for crimes such as larceny that are more likely to suffer from under-reporting rather than those which are typically reported, such as homicide and motor vehicle theft. However, our estimates provide little evidence of an ameliorative effect of IT on crime even taking into account the consequences of improved measurement.

As a final check, we employ two different instrumental variables (PC availability in the broader area and body armor use) that attempt to capture variation in the supply of and demand for IT exogenous to our organization and effectiveness measures. These instruments are of somewhat limited quality, but they support the hypothesis that IT adoption promotes organizational change. In summary, although we cannot address all alternative explanations for the IT-organization link, the weight of our evidence is most consistent with a causal effect of information technology on organizational structure, with the large technological changes driving IT adoption in the broader economy contributing to both computerization and increased organizational complexity within the police sector but having little apparent effect on productivity.

In the private sector context, some researchers have argued that a barrier to the 
success of IT may be the need to implement IT together with particular organizational changes, an application of the complementarity hypothesis first advanced formally by Milgrom and Roberts (1990). ${ }^{4,5}$ Although IT by itself may have little impact, its impact may be substantial when introduced within the context of an organizational and human resource system designed to take advantage of it. In the specific context of police work, the complementarity hypothesis takes one very salient form: Compstat. The system of practices summarized by this name was initially introduced in the New York Police Department by Police Commissioner William Bratton under Mayor Rudolph Giuliani's leadership and then spread throughout the country. The program aimed to combine real-time geographic information on crime with strong accountability by middle managers in the form of daily group meetings, geographic resource allocation, and data-intensive police techniques. The program was widely credited in the press and by policymakers with playing a substantial role in the recent precipitous drop in crime experienced by some cities. ${ }^{6}$

To test the complementarity hypothesis, we study the impact of information technology when it is adopted together with skilled officers, new problem-solving techniques, extensive use of 'output' information in evaluation and deployment of officers, and a geographic-based structure. ${ }^{7}$ Although the data available for testing this hypothesis are much shorter and more limited (questions on these type of practices were only introduced in the survey in 1997), they clearly endorse this hypothesis. We find crime clearance rates were an average of 2.2 percentage points higher in agencies implementing this integrated set of practices. Similarly, crime rates are negatively associated with Compstat use. Moreover, the individual practices composing Compstat have no

\footnotetext{
${ }^{4}$ In their analysis of modern manufacturing, Milgrom and Roberts (1990) argue that, given the existence of complementarities among organizational practices, a range of organizational choices may have to be altered together for a particular technological advance to improve efficiency. In the presence of complementarities success is not "a matter of small adjustments, made independently at each of several margins, but rather involve[s] substantial and closely coordinated changes in a whole range of the firm's activities." (p. 513)

${ }^{5}$ Brynjolfsson and Hitt (2000) review this literature.

${ }^{6}$ Some research has disputed the claim of a large effect of Compstat; see, for example, Levitt (2004) and Rosenfeld, Fornango, and Baumer (2005).

${ }^{7}$ Our approach is similar to Ichniowski, Shaw, and Prennushi (1997), who study complementarities among HRM practices and their impact on productivity. IT is not, however, a focus of their study.
} 
independent ameliorative impact on crime levels or clearance rates. ${ }^{8}$

We thus conclude that IT may improve police productivity, but such improvements only occur when IT is introduced in conjunction with certain organizational practices oriented to take advantage of new data availability. More generally, our results demonstrate that many of the forces identified in the labor literature on IT in profitmaximizing firms-such as IT-induced shifts in demand for skilled labor, heterogenous productivity effects of IT, and IT/management practice complementarities-are also apparent in public sector organizations.

\section{Data Description}

The data are drawn from the Law Enforcement Management and Administrative Statistics (LEMAS) series, a triennial survey of law enforcement agencies in the United States covering the years 1987-2003. ${ }^{9}$ Although not specifically designed as a longitudinal survey, the broad coverage of the survey makes it possible to identify numerous agencies at multiple points of time. ${ }^{10}$ The surveys provide rich data on a wide variety of police operations, including shift scheduling, equipment usage, agency structure and functions, officer compensation, and administrative policies. To supplement the LEMAS data, we have matched the surveyed agencies with annual arrest and offense data from the FBI's Uniform Crime Reports (UCR) and place-level demographic data from the Census where possible.

One of the strengths of this data set is that it contains questions on a variety of different types of IT use and covers a period of enormous IT expansion. Figure 1 plots aggregate trends in IT use by police agencies. The upper graph details use of different

\footnotetext{
${ }^{8}$ Again, the causal interpretation of this increase must be qualified. If a system of complementary changes must be undertaken, the fact that some departments choose not to undertake these changes may reflect some omitted variable, such as the quality of management of the department, in which case the $2.2 \%$ is biased upwards. This problem is common to a large extent to all of the literature on organizational change (see e.g. Ichniowski and Shaw (Forthcoming)).

${ }^{9}$ The 1996 survey was conducted in 1997, and an additional survey was conducted in 1999.

${ }^{10}$ All state police agencies and all agencies with 100 or more officers are automatically sampled with probability sampling for the remaining agencies. In each year roughly 3000 of the approximately 19000 U.S. law enforcement agencies are represented.
} 
types of information technologies, including PC's, mobile data terminals (typically used by officers to access vehicle, criminal background, or other information while in the field), and mainframes and servers. In 1987, fewer than $20 \%$ of the surveyed agencies used any computers, but over the next 12 years computer use showed substantial increases, with PC use growing more rapidly than more specialized technologies. By the end of the sample over $90 \%$ of responding agencies reported IT use. The large increase in mainframe and server use near the end of the sample is likely attributable to the increased importance of the Internet in the latter half of the 1990's.

The middle chart in Figure 1 details use of computerized data files by function. Growth trends in data use for arrests, service calls, and stolen property were comparable through the entire sample. The final chart demonstrates a significant asymmetry in IT adoption according to agency size. A substantial proportion of the largest police agencies already had computing technologies by 1987. In stark contrast, only 2 of the over 2200 departments with 100 or fewer employees in 1987 reported using computers. Between 1987 and 1990 there was widespread adoption of computers by mid-sized agencies, with the smallest agencies lagging behind until the final years of the sample.

Our preferred measure of computer usage is a computer index constructed as the proportion of nine computer/data functions present in an agency in a given year. ${ }^{11}$ The advantage of this index relative to simple dichotomous IT measures is that it captures not only the existence of IT within an organization, but the degree to which IT is used to perform disparate tasks. ${ }^{12}$ During our sample the computer index increases from an average of .11 in 1987 to .64 in 2003.

Table 1 provides summary statistics describing the measures of output, organizational structure, and worker skill that we employ in our analysis. The varying number of observations reflects the fact that not all survey items are available in all years and UCR and Census data were not available for all agencies. In total, approximately 8600 police agencies are represented at some point in the sample, with over 1800 agencies

\footnotetext{
${ }^{11}$ The nine functions we include are computer use for crime analysis, investigation, and dispatch and data record use for arrests, service calls, criminal histories, stolen property, traffic citations, and warrants.

${ }^{12}$ In Section 4 we demonstrate the our basic results are not sensitive to this choice of IT measure.
} 
registering observations in 4 or more sample years. Many of the police agencies in the sample are county or city agencies within moderately-sized jurisdictions, but university, state, and large city police departments are also represented. The areas represented are slightly poorer, less educated, and less diverse than the overall United States.

\section{Patterns in IT Adoption, Organizational Change, and Productivity}

In this section we examine our organizational and outcome measures for evidence regarding their relationship with computerization. In our basic analysis we use OLS regressions and separately report specifications including year or agency and year fixed effects and additional time trends. In all regressions we attempt to control for other relevant factors that may affect our outcomes of interest. If differential acquisition of information technology is driven by factors exogenous to the agency, such as variations in the cost of technology over time and place, these coefficients would reflect an effect of IT on our organizational measures. However, it may be the case that omitted factors or reverse causality explain some of the associations we find using OLS. In section 4 , we re-estimate the regressions from this section using instrumental variables as well other reasonable specifications. Accounting for possible endogeneity of IT adoption, limiting the sample, using alternative IT measures, and richly controlling for potential confounding factors does not alter our basic conclusions.

\subsection{Agency Size and Complexity}

To measure agency size, we count the total number of sworn and non-sworn personnel reported by each agency. ${ }^{13}$ The distribution of agency sizes is highly right-skewed, and the median size of surveyed agencies rose from 25 in 1987 to 57 in 2003. Among agencies reporting in all sample years, the median size also rose from 328 to 472 employees over the sample period, suggesting a general trend towards larger departments. In order to

\footnotetext{
${ }^{13}$ We consider part-time employees as equivalent to $\frac{1}{2}$ of a full-time employee.
} 
control for workload in our regressions relating industry size to IT use, we include as controls indicators for deciles of number of offenses reported by an agency.

We consider several measures of agency complexity. Our first measure of agency complexity is the agency's total number of special units. Special units are smaller groups of officers with specific expertise and focus on a particular crime class or administrative program, such as gang investigations or school outreach. In some cases officers are involved in special units as their primary assignment, while in other cases officers with general policing responsibility also participate in special units on a parttime or ad hoc basis. ${ }^{14}$ Unsurprisingly, agency size is highly correlated with special units as well as our other complexity measures. In our empirical analysis we control for agency size in all specifications.

Our next complexity measure is the number of hierarchical levels in the agency, which we infer based upon whether or not separate salary ranges were reported for chiefs, sergeants, and junior-level officers in the survey. This is a somewhat crude proxy for the degree of hierarchy in the agency given that many larger police agencies have substantially more than three administrative levels. Our final measure is the number of written departmental policies. ${ }^{15}$ This measure is likely affected by not only the complexity of the organization (a more complex organization requires more policies) but also the quality of management oversight and use of documentation, all factors that may be affected by IT.

The top rows of Table 2 demonstrate that IT use is positively and significantly associated with our measures of agency size and complexity. The coefficients on log employees are much larger in the specification without agency fixed effects, likely because of the enormous cross-agency size heterogeneity. Even the smallest point estimate of $8.5 \%$, however, suggests a substantial effect of IT on size. IT appears to promote specialization and use of written directives as well, although the coefficient estimates

\footnotetext{
${ }^{14}$ The special units that are consistent across sample years that we include are special units for child abuse, community crime prevention, family violence, drug education, drunk driving, missing children, police/prosecutor relations, career criminals, and victim assistance.

${ }^{15}$ The possible policies are policies governing general police conduct, use of deadly force, handling of domestic cases, and interactions with juveniles, the homeless, and the mentally ill.
} 
diminish as more fixed effects and trends are added to our regressions. Finally, IT is not significantly associated with the number of hierarchical levels after controlling for agency fixed effects and time trends.

\subsection{Agency Composition}

In addition to affecting the tasks performed by workers, new technologies also can potentially shift the types of workers employed by agencies. The LEMAS data differentiates sworn officers, which are typically officers with arrest powers, from other types of police employees. ${ }^{16}$ It also provides separate counts of the number of employees in field operations and technical support roles. Theoretically an IT-induced improvement in the productivity of arresting officers could lead to an increase or decrease in the field share of officers depending on the form of the policing production function. Many federal programs for funding IT improvements in police agencies, however, were instituted with the explicit goal of shifting police personnel from desk to street duty. ${ }^{17}$

Table 2 suggests that IT adoption has little connection to employment of sworn officers. The point estimates for all four specifications relating officers with arrest powers to IT use are negative and of small magnitude. Similarly, after controlling for agency-level heterogeneity there is little evidence that IT increases the proportion of workers assigned to field operations. Increases in IT intensity are associated with increases of 4-7\% in the percentage of staff that are assigned technical support roles. This increase is similar in magnitude to the increase in overall agency size, suggesting that the primary effect of IT on personnel is to enlarge the police department by adding employees that maintain the technology infrastructure as opposed to employees that perform more traditional police functions. ${ }^{18}$

\footnotetext{
${ }^{16}$ One caution regarding this data is that some officers may officially have arrest powers even if they essentially perform administrative duties.

${ }^{17}$ For example, the descriptive material for Making Officer Redeployment Effective (MORE), a Federal grant program administered by the Department of Justice Office of Community Oriented Policing Services (COPS), states, "The MORE program increases the time available to law enforcement professionals for community policing activities by funding technology that enables a department to operate more efficiently." (Office of Community Oriented Policing Services 2002)

${ }^{18}$ These results sharply contrast with Doms, Dunne, and Troske (1997), who find using panel data
} 


\subsection{Worker Skill}

Most years of the survey ask whether the department requires new entrants to have college experience, permitting us to directly link computer use to demand for collegeeducated labor. Although a number of papers have posited a link between increases in the demand for skilled labor and computerization (Mincer 1991, Bound and Johnson 1992), most past empirical studies of this proposition have relied on indirect evidence, such as cross-industry differentials in worker skill and computer use (Berman, Bound, and Griliches 1994, Autor, Katz, and Krueger 1998). Implicit in most models of computer-driven changes in skill premia is the notion that highly computerized firms would be more likely to hire better educated workers because such workers can more productively use the available information technology.

A lower row of Table 2 reports linear probability regressions ${ }^{19}$ of the computer index on an indicator for whether an agency requires entrants to have prior college experience. To account for factors potentially correlated with computer use and demand for education, all specifications include controls for agency size as well as the income level and adult educational distribution in the agency's geographic area. A shift to complete computerization is associated with a 3.3\% increase in the probability of requiring college education, a sizable increase given that only about $13 \%$ of agencies require college education. Indeed, in 1997, agencies reporting PC use were twice as likely to report college requirements for entering workers than those without.

In addition to the relationship between worker education and IT, some past authors have suggested that IT adoption can impose increased training requirements for new workers, leading to skill increases generated within the firm (Bresnahan, Brynjolfsson, and Hitt 2002). The bottom row of Table 2 reports estimates of the effect of IT adoption on the number of training hours provided for new hires by the police agency. Although controlling for year fixed effects reduces the estimated effects of IT adoption somewhat, in all specifications the estimates are large and highly statistically significant. ${ }^{20}$

that increases in technology were not associated with increases in the non-production share of labor.

${ }^{19}$ Logit and probit regressions provide similar results.

${ }^{20}$ Although the magnitudes of the estimated effect of IT use on training appear large, they are not 
IT use may affect training through two channels. One direct consequence of IT adoption is the necessity of training new officers on the appropriate use of the technology. Such training may be particularly necessary when agencies use IT specialized for police work, such as mobile terminals or proprietary record-keeping software. Another possibility is that the incorporation of information technology into the training process (for example, by allowing for computer-based interactive activities) increases the value of training hours for activities not directly involving computers. Unfortunately, the training data do not contain additional detail that might permit disentanglement of these mechanisms. However, because we do have information on different IT functions, we can examine the extent to which increased training is associated with generalpurpose IT such as PCs, which have the potential to affect the overall training process, versus more specialized technologies.

Table 3 tests this proposition by entering PC use and mobile computer use individually into the training regression. We posit that mobile data computers, which are typically specially designed systems that provide officers with in-vehicle access to crime information, cannot enhance general training but likely require device-specific instruction. Although the estimated coefficients for both types of IT are positive and significant, the coefficient on mobile terminals is more than twice as large as that on PCs. The control coefficients indicate that larger police agencies and agencies with college requirements also conduct more training. These results suggest that the increase in training is due primarily to actual use of new information technologies as opposed to technical improvements in training.

\subsection{Policing Outcomes}

One way in which our analysis departs from prior work is our use of public-sector data. Many past studies of IT have focused on manufacturing industries with intuitive output

unreasonable given the enormous increase in training observed over the sample period. Between 1987 and 1990, the period which saw the largest rise in adoption of IT, average training hours rose from 163 to 633 , an almost four-fold increase. By 2003, almost half of sampled agencies required new officers to undergo more than 6 months of training. 
measures such as productivity and profits. Although some authors have argued that a primary role of IT in police organizations is to improve police problem solving(Brown and Brudney 2003), there is little empirical evidence connecting IT use to improved enforcement. In this section we first examine the extent to which IT enhancements are associated with increases in clearance rates ${ }^{21}$. To examine the deterrent aspect of enforcement we also consider offending rates per population as dependent variables. To examine possible asymmetries in the usefulness of IT across crimes, we also separately examine violent and property arrests. ${ }^{22}$. Although arrest and offending measures are indicators of enforcement output, these measures must be viewed with appropriate caution. In particular, simple arrest and offending measures fail to account for conviction rates, elimination of concentrated areas of crime, and other factors that may enter into the objective functions of police departments.

Table 4 reports our results. Although there appears to be a positive effect of IT on clearance rates in the first specification, the effects disappear after controlling for placelevel heterogeneity with agency fixed effects. The data do not suggest that agencies that increased IT substantially over the sample period had superior clearance rates to those with little IT adjustment. Estimates for offending rates, on the other hand, are positive and sometimes statistically significant, although including agency fixed effects and trends weakens the relationship somewhat. For property crime, an increase of .53 in the computer index is associated with a .0016 percentage point, or roughly $5 \%$ increase in offenses.

The final rows of Table 4 consider the possibility that the effect of IT is to allow agencies to achieve the same clearance rates with less risk to officers. Such safety enhancements might occur through substitution away from street officers to administrative personnel or by providing information to officers that allows them to identify risky individuals and locations. The departmental organization data provided some

\footnotetext{
${ }^{21}$ The clearance rate is the number of crimes for which an arrest was made divided by the total number of offenses reported to police. Because arrests can occur for crimes committed in prior years, clearance rates can be above 1 . For a more detailed discussion of the use of clearance rates in crime research see Skogan and Frydl $(2004,160)$.

${ }^{22}$ Further disaggregation to individual index crimes provides comparable results
} 
evidence of the former effect, although the evidence regarding percent sworn personnel was mixed.

Increases in the IT index are generally associated with decreases in both officers assaulted and officers killed, although estimated coefficients are statistically significant only in the more parsimonious specifications. The fact that the effect on officers assaulted disappears after controlling for computer index-year trends may reflect differential investment patterns in other technologies that can improve officer safety by high and low computer agencies.

Given the positive association between IT and firm productivity documented by past researchers [e.g., Lichtenberg (1995), Stiroh (2002), Black and Lynch (2001)] and widespread use of IT in modern police departments, our finding that computers contribute little to productivity may seem somewhat surprising. One possibility is that the increase in size, specialization, and written directives we document does not reflect augmented structure, but rather the increased 'administrative clutter that often accompanies IT deployments. Such an interpretation is consistent with Goolsbee and Guryan (2006) and Ellison (2002), who suggest in very different contexts that the primary effects of IT may be to alter the production process without improving production outcomes. $^{23}$

In the next section of the paper we examine whether these results may be driven by misspecification, endogeneity, or omitted variables.

\section{Robustness Checks}

\subsection{Alternative IT Measures and Samples}

In Appendix Table A-1 we examine the robustness of our basic results to alternative choices of computerization measure. Specification I uses a binary variable for PC use in place of the computer index as a measure of IT while specification II uses an indicator

\footnotetext{
${ }^{23}$ Goolsbee and Guryan (2006) find that more access to the Internet by schools does not measurably increase student achievement, while Ellison (2002) suggests that IT may result in a shift in from a focus on content to a focus on style.
} 
for any computing technology. Specification III improves the panel quality of the data by limiting the analysis to agencies observed in 4 or more time periods. Specification IV omits 1987 from the sample to assess whether the results are driven mainly by the large increase in computer use that occurred between 1987 and 1990. The final specification limits the analysis to agencies which reported some IT use in their first year in the sample. This specification examines whether the observed effects can be attributed to changes in IT intensity as opposed to simple adoption of any IT.

Employing different measures of IT use changes the results little, although the alternative measures are more weakly associated with worker skill and training than the index. The results for agencies observed in 4 or more years, which tend to be slightly larger agencies, are also consistent with the baseline. Limiting the analysis to 1990-1999 reduces the estimated coefficients on technical support staff and training by about half, which is unsurprising since it seems likely that the largest training and administrative changes would occur during the early stages of IT adoption. Agencies with IT in 1987 saw the smallest increases in technical support staff and these agencies, which are much more likely than average to include college requirements, saw relatively small effects of IT on demand for skilled entrants. Overall, the results appear fairly robust to sample and specification changes.

\subsection{Alternative Interpretations}

Our OLS results, while robust to sample changes, may not reflect a causal relationship between IT and organization. Clearly it is possible that agencies adopt new technology because of organizational restructuring, in which case our estimates reflect causality running from outcomes to IT, or that a third factor causes both IT and organization to change together. In this section we conduct specific tests of some of the main alternative non-causal explanations and then employ instrumental variables strategies to address endogeneity more generally. Although no single approach we employ can completely rule out endogeneity as an explanation for our results, taken as whole the evidence is most consistent with a causal effect of IT on organizations. 
Pre-existing trends: Departments adopting IT could be those that observed previous negative trends in performance or other variables. As the department reforms, it installs IT systems and adopts a wide range of changes that lead to upward biases of the impact of IT - a form of the "Ashenfelter dip." ${ }^{24}$ We examine this by replicating our analysis including leads in the computer index as additional explanatory variables. ${ }^{25}$ Any tendency toward decay in our dependent variables prior to the introduction of IT should be manifest in negative coefficients on these leads.

Table 5 demonstrates that for our organizational measures there is little evidence of an Ashenfelter dip, with none of the coefficients on leads statistically different from zero and equal numbers of positive and negative point estimates. The coefficients on the index itself, in contrast, typically maintain the same sign and significance as in the baseline.

Delayed effects: Another potential explanation for the apparent lack of relationship between IT and outcomes is that IT only improves policing after an initial learning period. The second specification in Table 5 tests for this possibility with lags of the computer index as additional regressors. Given the 3-year separation between most surveys, it seems likely that any delayed benefits of IT implementation would be captured by this lagged term ${ }^{26}$. The coefficients on the lagged term, however, are generally negligible and statistically indistinct from zero. The coefficients on the contemporaneous index, in contrast, remain positive and significant for the agency size measures and officer training.

Previous mismanagement: An alternative interpretation for our results is that departments that reorganize and adopt IT are those that were previously underperforming and acquired new management. IT has no causal effect in this case.

The 1987 LEMAS survey includes questions on the number of civil litigation cases

\footnotetext{
${ }^{24}$ Ashenfelter (1978) observed that participants in training programs had unexplained drops in pay just before enrollment.

${ }^{25}$ One limitation of such analysis in our setting is that many agencies are observed in only a small number of years. Introducing leads thus changes our sample composition somewhat.

${ }^{26}$ In unreported regressions we include an additional lag and obtain similar results.
} 
filed against the agency in that year. ${ }^{27}$ One reasonable conjecture is that more troubled agencies would have experienced higher levels of litigation. If being troubled drives both organizational change and IT change, we should observe different trajectories for the IT index for agencies with high versus low initial levels of litigation. Appendix Table A-2 examines this possibility by regressing long differences in the computer index on the litigation level in 1987 and finds little evidence that agencies with high litigation exhibited differential IT changes. The magnitudes of the differences in IT change between high and zero litigation agencies are small relative to overall change and not statistically different from zero.

Size-related heterogeneity: Failure to adequately control for agency size could also suggest a spurious relationship between IT and our organizational variables if, as agencies grow, they require increased IT as well as a more specialized, educated workforce. This concern seems particularly salient given the strong relationship between IT use and agency size documented in Figure 1. We have already attempted to address this possibility by including controls capturing the relevant aspect of agency, community, or workload size in all of our basic specifications.

As an additional check we allow for highly flexible effects of size on the organizational variables by re-estimating the regressions in Tables 2 and 4 including a full set of interactions between indicators for deciles of agency size and year. We also rerun the analysis limiting the sample to agencies with fewer than 25 employees or agencies with greater than 100 employees. The results of these regressions are reported in Table 6. The findings for agency size, technical support staff, training, and demand for college are consistent with the baseline.

The middle columns of Table 6 report additional checks of the hypothesis that our results are driven by general reorganization associated with population growth. Column IV includes population decile-year interactions. Column V limits the analysis to only places in which population fell over the course of the sample. Column VI includes only agencies in areas in which the population changed by $10 \%$ or less. Column VII

\footnotetext{
${ }^{27}$ Unfortunately this question was not asked in subsequent years.
} 
builds a sample of agencies in comparably sized areas by considering only agencies with base population between 80000 and 120000. Areas with declining or stable populations yield point estimates of similar magnitude to the universe of agencies. Thus, it does not appear that community growth is driving both IT acquisition and organizational restructuring. The evidence linking IT with improved officer safety is much weaker after accounting for community growth.

Agency resources: A final concern is that agencies with greater financial resources may both purchase IT and implement superior organizational practices, such as hiring more workers and providing better training to existing workers. Column VIII of Table 6 reports regressions that attempt to flexibly control for differences in resource availability by interacting the $\log$ of equipment expenditures ${ }^{28}$ with indicators for deciles of equipment expenditure. Although these controls do not perfectly capture resource differences across agencies, encouragingly, their inclusion does not substantively alter our results.

Improved measurement: The widespread adoption of various forms of information technology by police agencies during the 1990's appears at odds with our robust findings that general IT has no net relationship to clearances and is actually associated with an increase in offense rates. One potential explanation for these results is that our index, which provides a fairly general measure of IT intensity, could mask heterogenous effects of different information technologies on our enforcement outcomes. For example, offenses might be higher in places with more computers simply because officers may be more willing to file police incident reports when filing can be done using computers instead of by hand. Other technologies, such as technologies that improve officer deployment, may at the same time have a deterrent effect on crime.

To disentangle these potentially competing effects of IT, we exploit the detailed use questions in the LEMAS survey. We measure IT use for report writing using an indicator for whether computers are used for record keeping. To measure IT-enhanced deployment, we use the average of indicators for computer use in dispatch, fleet man-

\footnotetext{
${ }^{28}$ Unfortunately, information on annual expenditures on equipment is available only from 1987 to 1997 and the value was estimated by some agencies.
} 
agement, and manpower allocation. ${ }^{29}$

Table 8 reports regressions entering the record keeping and deployment variables simultaneously as explanatory variables for offenses. For total arrests, the coefficient on the record keeping computer use indicator is positive and significant, suggesting that offense reports increase by $10 \%$ once computers are available for record keeping. Computer use to enhance officer deployment, in contrast, enters negatively and marginally significantly, consistent with a deterrent effect of improved deployment capabilities. The additional columns replicate the analysis on different individual crimes to provide an additional test of our interpretation. Given the seriousness and rarity of homicide, homicide is almost universally reported. Similarly, because auto insurance companies typically require police reports in the case of motor vehicle theft, computerization is less likely to affect reporting for this crime. For these two crimes the estimated coefficients on the record keeping variable are statistically indistinguishable from zero. It seems unlikely that improved police deployment could exert a deterrent effect on rape $^{30}$, and indeed the coefficient on the deployment index is small and statistically insignificant.

Apparently one explanation for the positive association between general IT and offending is that reporting technologies increase crime reports even while other technologies may deter crime. However, this analysis does not allow us to reverse the conclusion that IT had limited impact on productivity. Adjusting the coefficients on the total offense rate in Table 4 to account for improved reporting yields coefficients close to zero. ${ }^{31}$ In addition, effects of IT on patterns in violent crime, which are less likely to be affected by reporting problems, are negligible. The estimated effects of deployment technologies are quite modest. Thus, the lack of positive impact of IT on

\footnotetext{
${ }^{29}$ Our results are not sensitive to separately or simultaneously entering in individual deployment measures.

${ }^{30}$ Braga (2001) reviews studies documenting the effects of police patrols on various types of crime and disorder. None of the major studies includes rape as an outcome of interest.

${ }^{31}$ The proportion of agencies using computers for record keeping increased from $14 \%$ to $76 \%$ between 1987 and 2003. Based on the coefficients in Tables 8, this increase would translate to a $6 \%$, or roughly .002 percentage point change in the offense rate, which should be subtracted from the coefficients on the total offense rate in Table 4 .
} 
police productivity is not a statistical artifact.

Other Forms of Endogeneity: We attempt to address additional sources of endogeneity using instrumental variables. Our search for appropriate instruments is significantly complicated by our requirement for data sources that exhibit both geographic variation and which are available in the earlier years of our sample. We consider two instruments for the computer index. The first is the percentage of workers in an agency's state and year who use computers at work. The work computer-use data was obtained from CPS Computer Use Supplement surveys and has been used in a number of past studies of computerization including Krueger (1993). ${ }^{32}$ Areas with many work computer users likely had greater availability of computer hardware and expertise as well as increased exposure to computers among the general population; both phenomena would likely increase the likelihood of computer adoption. Conceptually, this instrument attempts to capture exogenous variations in IT supply and thus helps address factors such as prior crime increases or unobservable managerial ability that may affect our outcomes of interest and also influence IT adoption.

The second instrument we consider is an indicator variable for whether or not an agency provides body armor to officers. This instrument attempts to capture idiosyncratic willingness of agencies to invest in new police technologies. Given that body armor represents a substantial expense for police agencies ${ }^{33}$ and vest designs are constantly evolving, body armor is more likely to be available in "technology-minded" agencies. Here we thus assume that there are exogenous factors determining the technology orientation of an agency that affect demand for both body armor and IT.

Although with any instrumental variables analysis there are potential threats to the validity of the instruments, insofar as these combined instruments provide comparable estimates to the baseline, we might interpret this as evidence that our primary results are not driven by endogeneity. In particular, given that our instruments are designed to

\footnotetext{
${ }^{32}$ Because the supplement is available in only selected years, we use linear interpolation across years where necessary to generate computer use measures for the appropriate years. Unfortunately, the sample size of the CPS precludes calculating computer use measures at finer levels of geographic disaggregation than the state.

${ }^{33} \mathrm{~A}$ typical bulletproof vest for a single officer costs around $\$ 500$ dollars.
} 
capture variation in IT that should not be related to past crime trends or management reform, we provide further evidence here against two alternative hypothesis, namely, that crime spikes precede reorganizations and IT adoption or that agencies which are poorly managed or poorly functioning acquire new managers who undertake reforms including computerization.

Table 7 reports the instrumental variables estimates. Although for a few of the measures with more limited availability (special units, \% field operations, and \% sworn) the instruments perform poorly, the coefficients on both instruments are generally significantly positive with fairly large first-stage F-statistics for the combined instruments. The magnitudes of the first-stage coefficients suggest that technology-orientation as proxied by body armor availability generates a slight increase in IT use with a more substantial effect arising from changes in availability of IT. Over the sample period, the mean change in work computing of .25 is predicted to raise the computing index by roughly .1.

The IV results for the departmental size and complexity measures are comparable in sign to our initial results and continue to suggest that IT increases department complexity. For the educational and training measures, in contrast, IV provides weaker evidence of skill/technology complementarity than OLS. For offense rates, the IV estimates remain positive and statistically significant, with IT-induced offense increases concentrated among property crimes. The somewhat implausibly large, negative IV coefficient on assaults may reflect failure of the exclusion restriction for body armor and this particular outcome.

\section{Complementarities in Law Enforcement Manage- ment}

One possible explanation for the small effect of IT on police effectiveness is that IT increases police department productivity only in conjunction with a broader set of practices. Milgrom and Roberts (1990) proposed such a complementarity hypothesis 
in the manufacturing context, contrasting two basic systems, modern versus traditional manufacturing. Subsequent work, such as Bresnahan, Brynjolfsson, and Hitt (2002), Brynjolfsson and Hitt (2003), and Bartel, Ichniowski, and Shaw (2005) has identified empirical examples of complementarities between IT use and management practices.

In the law enforcement context, modern policing has been most closely identified with the Compstat system first introduced by the New York Police Department in 1994 by Commissioner William Bratton. In the popular imagination, Compstat is characterized by two elements: the real-time mapping of crime, and the notorious earlymorning meetings where commanders must show they understand and are reacting to the crime patterns projected on overhead screens. The program, in actuality, has additional elements. Weisburd, Mastrofski, McNally, Greenspan, and Willis (2003, 427) argue that Compstat is composed of the following six elements: (1) statement of the measurable goals of the department; (2) internal accountability, particulary through Compstat meetings - managers are accountable for understanding crime patterns and reacting to them; (3) geographic organization of command - district commanders have authority and resources to accomplish goals within areas; (4) empowerment of middle managers; (5) data driven problem identification and assessment; and (6) innovative problem solving tactics. ${ }^{34}$

Our data allow us to identify four management techniques corresponding to elements identified by Weisburd, Mastrofski, McNally, Greenspan, and Willis (2003). In particular, we consider (1) use of information technology for crime data collection and analysis (5 above), (2) a problem-solving paradigm (6 above), (3) use of feedback for priority-setting and evaluation (relating to 1, 2, and 5 above), and (4) a geographicbased deployment structure (3 above). Following the economics literature on skill complementarities, we include a fifth management practice - the use of more highly educated officers.

Ideally, to test the complementary explanation we might use regressions similar

\footnotetext{
${ }^{34}$ Other accounts coincide with the broad elements although not on all the details. For example, the New York Times summarizes the program thus: "specialized units, statistics-driven deployment, and a startling degree of hands-on leadership" (Dewan 2004).
} 
to those in Section 3 with separate and interacted measures of IT and management practices as explanatory variables. Unfortunately, this approach is limited by our available data in two important ways. Most of the questions regarding management practices identified by Weisburd, Mastrofski, McNally, Greenspan, and Willis (2003) as key to improving police performance were not asked in the LEMAS survey prior to 1997, a time by which many larger agencies had already implemented Compstat or similar programs. The other major data limitation is that because of the subjective nature of some of the questions regarding management practices, there appears to be some inconsistency across years in reported practices, potentially rendering inferences based upon within-agency time-series variation in practices misleading. ${ }^{35}$ To overcome these limitations, we average responses to individual survey questions across years to develop an agency-level indicator for each of the aforementioned management practices covering the period 1997-2003. We then define Compstat agencies as those which simultaneously had elements of all five key management techniques in at least half of the sample years. ${ }^{36}$ Our regressions examining complementarities thus exploit crosssectional variation in IT and management practices.

Table 9 reports regressions of the average agency clearance rate over 1997-2003 on agency-level indicators for Compstat use and separate indicators for each of the five components comprising a Compstat system. Separate specifications are reported for total, violent, and property crimes with and without demographic controls. The results are striking. Whereas the estimates on each of the individual management practices are of negligible magnitude and generally statistically indistinguishable from zero, the combination of practices into a Compstat system yields positive and significant effects on clearance rates. The coefficient estimates of around $2 \%$ imply a roughly $10 \%$ gain relative to the average clearance rate of $22 \%$. For violent crimes, which in many cases

\footnotetext{
${ }^{35}$ For example, one survey item asks whether officers use a particular police problem-solving methodology known as SARA (scanning, analysis, response, and assessment). The Little Rock PD reported using SARA in 1997, 1999, and 2003 but not 2000 while the Bakersfield PD reported using SARA in 2000 but not 1999, 1997, or 2003. The police in Hillsborough, CA reported using SARA in 1997 and 2000 but not 1999 and 2003.

${ }^{36}$ The construction of these variables is described in greater detail in the Appendix.
} 
are an area of particular investigative emphasis, the point gains are even greater.

Table 10 reports comparable regressions with offense rates as the dependent variable. Whereas some of the individual management practices appear positively associated with offense rates, consistent with our finding in section 4 regarding reporting, use of a Compstat system is negatively and significantly related to total and property offending. The estimated effects of a Compstat system on crime rates are small to moderate - the estimates imply, for example, that having a Compstat system has an equivalent effect on crime rates as a 4.4 percentage point increase in the poverty rate. ${ }^{37}$

Given that we only have approximate measures of the Compstat practices and are forced by data limitations to rely on cross-sectional variation, our results on the role of complementarities are only suggestive. Taken together, however, the regressions in Tables 9 and 10 support the hypothesis that an additional reason for the weak aggregate relationship between general IT and policing outcomes may be that while many agencies utilize some type of IT, relatively few have yet implemented all of the complementary management practices that allow IT to impact police effectiveness. ${ }^{38}$

\section{Conclusions}

This paper provides new evidence on the role of IT in the public sector. As in firms, IT and worker skill are complementary in police agencies, with IT adoption influencing both the demand for college-educated employees and internal training levels. Evidence on the impact of IT on public-sector performance is more sobering, however. It appears that IT results in 'bureaucratization-increased agency size, greater use of written directives, and a larger share of non-production personnel-with little or no impact on

\footnotetext{
${ }^{37}$ Given our findings here, one natural question is whether the outcome regressions reported previously suffer from omitted variable bias due to failure to control for management practices. If the management practices are positively correlated with computer use (as they are in our sample) and are actually beneficial in solving cases or deterring crimes, the omission would bias our estimates towards finding an effect, which we do not.

${ }^{38}$ One natural question arising from these findings is why Compstat or similar programs are not more widely used by police agencies. Possible factors limiting Compstat adoption include the high monetary cost of implementing all the necessary practices, police union resistance to higher accountability standards, and diffusion lags in knowledge of Compstat management techniques.
} 
productivity. One finding qualifies this pessimistic assessment: while the effects of general IT on crime fighting and deterrence are statistically insignificant (in spite of our large samples), this effect becomes relatively large when IT adoption is undertaken as part of a whole package of organizational changes. These results are a clear endorsement of the complementarity hypothesis. Police departments, like firms, are likely to enjoy the benefits of computerization only when they identify the specific ways the new information and data availabilities interact with existing organizational practices and make adjustments accordingly.

Looking at more specific uses of computers, we also find that some computing technologies increase recorded crime, which appears as lower productivity. More generally, computers may themselves alter the quality and type of data available to researchers in ways that obscure productivity computation. Distinguishing the different channels through which IT might impact not only performance, but also its measurement, remains an important area for future research. 


\section{References}

Acemoglu, D., P. Aghion, C. Lelarge, J. V. Reenan, and F. Zilibotti (2006): "Technology, Information and the Decentrealization of the Firm," Discussion paper, MIT.

Aral, S., E. Brynjolfsson, and M. V. Alstyne (2007): "Information, Technology and Information Worker Productivity: Task Level Evidence," NBER Working Paper 13172, National Bureau of Economic Research, Inc.

Arrow, K. (1974): The Limits of Orgnaization. Norton.

Ashenfelter, O. C. (1978): "Estimating the Effect of Training Programs on Earnings," The Review of Economics and Statistics, 60(1), 47-57.

Autor, D. H., L. F. Katz, and A. B. Krueger (1998): "Computing Inequality: Have Computers Changed The Labor Market?," The Quarterly Journal of Economics, 113(4), 1169-1213.

Bartel, A. P., C. Ichniowski, and K. L. Shaw (2005): "How Does Information Technology Really Affect Productivity? Plant-Level Comparisons of Product Innovation, Process Improvement and Worker Skills," NBER Working Paper 11773, National Bureau of Economic Research, Inc.

Berman, E., J. Bound, and Z. Griliches (1994): "Changes in the Demand for Skilled Labor within U.S. Manufacturing: Evidence from the Annual Survey of Manufactures," The Quarterly Journal of Economics, 109(2), 367-97.

Black, S. E., And L. M. Lynch (2001): "How To Compete: The Impact Of Workplace Practices And Information Technology On Productivity," The Review of Economics and Statistics, 83(3), 434-445.

Bolton, P., and M. Dewatripont (1994): "The Firm as a Communication Network," The Quarterly Journal of Economics, 109(4), 809-39.

Bound, J., And G. Johnson (1992): "Changes in the Structure of Wages in the 1980's: An Evaluation of Alternative Explanations," American Economic Review, $82(3), 371-92$.

Braga, A. A. (2001): "The Effects of Hot Spots Policing on Crime," ANNALS of the American Academy of Political and Social Science, 578(1), 104-125.

Bresnahan, T. F., E. Brynjolfsson, and L. M. Hitt (2002): "Information Technology, Workplace Organization, And The Demand For Skilled Labor: FirmLevel Evidence," The Quarterly Journal of Economics, 117(1), 339-376.

Brown, M. M., And J. L. Brudney (2003): "Learning Organizations in the Public Sector? A Study of Police Agencies Employing Information and Technology to Advance Knowledge," Public Administration Review, 63(14), 30-43. 
Brynjolfsson, E., And L. M. Hitt (2000): "Beyond Computation: Information Technology, Organizational Transformation and Business Performance," Journal of Economic Perspectives, 14(4), 23-48.

- 2003): "Computing Productivity: Firm-Level Evidence," Review of Economics and Statistics, 85(4), 793-808.

Caroli, E., and J. V. Reenen (2001): "Skill-Biased Organizational Change? Evidence From A Panel Of British And French Establishments," The Quarterly Journal of Economics, 116(4), 1449-1492.

Dewan, S. K. (2004): "New York's Gospel Of Policing by Data Spreads Across U.S.," New York Times, April 28, pg. A1.

Doms, M., T. Dunne, and K. R. Troske (1997): "Workers, Wages, and Technology," The Quarterly Journal of Economics, 112(1), 253-90.

Ellison, G. (2002): "Evolving Standards for Academic Publishing: A q-r Theory," Journal of Political Economy, 110(5), 994-1034.

Garicano, L. (2000): "Hierarchies and the Organization of Knowledge in Production," Journal of Political Economy, 108(5), 874-904.

Goolsbee, A., And J. Guryan (2006): "The Impact of Internet Subsidies in Public Schools," The Review of Economics and Statistics, 88(2), 336-347.

ICHNiOWski, C., AND K. SHAW (Forthcoming): "Insider Econometrics," in Handbook of Organizational Economics, ed. by R. Gibbons, and J. Roberts.

Ichniowski, C., K. Shaw, and G. Prennushi (1997): "The Effects of Human Resource Management Practices on Productivity: A Study of Steel Finishing Lines," American Economic Review, 87(3), 291-313.

Krueger, A. B. (1993): "How Computers Have Changed the Wage Structure: Evidence from Microdata, 1984-1989," The Quarterly Journal of Economics, 108(1), $33-60$.

Lehr, W., And F. Lichtenberg (1999): "Information Technology and Its Impact on Firm-Level Productivity: Evidence from Government and Private Data Sources, 1977-1993," Canadian Juornal of Economics, 32(2), 335-362.

LevitT, S. D. (2004): "Understanding Why Crime Fell in the 1990s: Four Factors That Explain the Decline and Six That Do Not," Journal of Economic Perspectives, 18(1), 163-190.

LichtenberG, F. (1995): "The Output Contributions of Computer Equipment and Personnel: A Firm-Level Analysis," Economics of Innovation and New Technology, 3(3), 201-218. 
Milgrom, P., And J. Roberts (1990): "The Economics of Modern Manufacturing: Technology, Strategy, and Organization," American Economic Review, 80(3), 51128.

Mincer, J. (1991): "Human Capital, Technology, and the Wage Structure: What Do Time Series Show?," NBER Working Papers 3581, National Bureau of Economic Research, Inc.

Office of Community Oriented Policing Services (2002): "COPS Fact Sheet," Washington D.C., U.S. Department of Justice.

Radner, R., And T. V. Zandt (1992): "Information Processing in Firms and Returns to Scale," Annales d'Economie et de Statistique, 25(26), 265-298.

Rajan, R., And J. Wulf (2006): "The Flattening Firm: Evidence from Panel Data on the Changing Nature of Corporate Hierarchies," Review of Economics and Statistics, 88(4), 759-773.

Rosenfeld, R., R. Fornango, and E. Baumer (2005): "Did Ceasefire, Compstat, and Exile Reduce Homicide?," Criminology and Public Policy, 4(3), 419-449.

Skogan, W., And K. FrydL (eds.) (2004): Fairness and Effectiveness in Policing: The Evidence. National Academies Press.

Stiroh, K. J. (2002): "Information Technology and the U.S. Productivity Revival: What Do the Industry Data Say?," American Economic Review, 92(5), 1559-1576.

Weisburd, D., S. D. Mastrofski, A. M. McNally, R. Greenspan, and J. J. Willis (2003): "Reforming to Preserve: Compstat and Strategic Problem Solving in American Policing," Criminology and Public Policy, 2(3), 421-456. 
Table 1: Summary Statistics

\begin{tabular}{|c|c|c|c|c|c|}
\hline Measure & $\mathrm{N}$ & Mean & SD & Min & $\operatorname{Max}$ \\
\hline \multicolumn{6}{|l|}{ Computerization Measures } \\
\hline Computer index & 19461 & 0.509 & 0.362 & 0 & 1 \\
\hline PC use & 13720 & 0.638 & 0.481 & 0 & 1 \\
\hline Computerized record keeping & 16294 & 0.632 & 0.482 & 0 & 1 \\
\hline \multicolumn{6}{|l|}{ Departmental Size and Complexity } \\
\hline Number of employees & 19893 & 197 & 959 & 0.5 & 55929 \\
\hline Number of special units & 19461 & 1.12 & 2.26 & 0 & 8 \\
\hline Organizational levels & 15216 & 2.82 & 0.50 & 1 & 3 \\
\hline Total written directives & 14639 & 3.95 & 2.03 & 0 & 6 \\
\hline \multicolumn{6}{|l|}{ Departmental Organization } \\
\hline$\%$ officers with arrest powers & 19893 & 0.785 & 0.171 & 0 & 1 \\
\hline$\%$ field operations staff & 5549 & 0.606 & 0.193 & 0.003 & 0.995 \\
\hline$\%$ technical support staff & 7764 & 0.120 & 0.117 & 0 & 0.877 \\
\hline \multicolumn{6}{|l|}{ Worker Skill and Training } \\
\hline College requirement for new officers & 16164 & 0.128 & 0.334 & 0 & 1 \\
\hline Hours of training for new officers & 15712 & 669 & 472 & 0 & 2080 \\
\hline \multicolumn{6}{|l|}{ Arrests, Offenses, and Officer Injury } \\
\hline Total crime clearance rate & 14793 & 0.229 & 0.164 & 0 & 1.083 \\
\hline Violent crime clearance rate & 13920 & 0.559 & 0.272 & 0 & 1.095 \\
\hline Property crime clearance rate & 14525 & 0.188 & 0.147 & 0 & 1.083 \\
\hline Total offense rate & 14773 & 0.034 & 0.033 & 0 & 0.496 \\
\hline Violent offense rate & 14781 & 0.004 & 0.006 & 0 & 0.203 \\
\hline Property offense rate & 14777 & 0.030 & 0.030 & 0 & 0.495 \\
\hline Officers assaulted & 9458 & 63.7 & 290 & 0 & 9024 \\
\hline Officers killed & 9458 & 0.019 & 0.159 & 0 & 4 \\
\hline \multicolumn{6}{|l|}{ Demographic Characteristics } \\
\hline Total population & 19529 & 225608 & 1282226 & 0 & 35484453 \\
\hline$\%$ Black & 19362 & 0.103 & 0.159 & 0 & 1 \\
\hline \% Hispanic & 19362 & 0.066 & 0.133 & 0 & 1 \\
\hline Poverty rate & 19362 & 0.137 & 0.082 & 0 & 0.657 \\
\hline Median household income & 19362 & 39173 & 15743 & 4208 & 202242 \\
\hline \% high school graduate & 19362 & 0.763 & 0.112 & 0.203 & 1.000 \\
\hline$\%$ college graduate & 19362 & 0.200 & 0.124 & 0 & 0.883 \\
\hline
\end{tabular}

Note: Computerization and other organizational measures are taken from the LEMAS survey. Arrests are from FBI UCR data. Demographic information corresponds to the area covered by each agency and are taken from the 1990 and 2000 Census with linear interpolation across years. 
Table 2: Relationship Between IT Use and Organizational Structure

\begin{tabular}{l||ccccc} 
Dependent Variable & $(\mathbf{I})$ & $(\mathbf{I I})$ & $(\mathbf{I I I})$ & $(\mathbf{I V})$ & $(\mathbf{V})$ \\
\hline \hline Departmental Size and Complexity & & & & & \\
Log(Number of employees) & $.514^{* *}$ & $.0842^{* *}$ & $.0872^{* *}$ & $.0560^{* *}$ & $.0637^{* *}$ \\
& $(.0355)$ & $(.0100)$ & $(.00955)$ & $(.0107)$ & $(.0103)$ \\
Number of special units & $2.78^{* *}$ & $.445^{* *}$ & $.451^{* *}$ & $.333^{*}$ & $.299^{*}$ \\
& $(.160)$ & $(.146)$ & $(.149)$ & $(.154)$ & $(.138)$ \\
Organizational levels & $.0410^{* *}$ & .0214 & .0172 & -.0159 & -.00219 \\
& $(.00997)$ & $(.0129)$ & $(.0129)$ & $(.0147)$ & $(.0111)$ \\
Total written directives & $1.54^{* *}$ & $1.71^{* *}$ & $1.68^{* *}$ & $.989^{* *}$ & $.927^{* *}$ \\
& $(.0494)$ & $(.0711)$ & $(.0715)$ & $(.0743)$ & $(.0661)$ \\
Departmental Organization & & & & & \\
\% officers with arrest powers & -.00591 & .00557 & .00681 & -.00287 & .00443 \\
& $(.00544)$ & $(.00475)$ & $(.00475)$ & $(.00521)$ & $(.00434)$ \\
\% field operations staff & $.0720^{* *}$ & -.00709 & -.00893 & .00212 & -.00901 \\
& $(.0148)$ & $(.00790)$ & $(.00772)$ & $(.00827)$ & $(.00774)$ \\
\% technical support staff & $.0642^{* *}$ & $.0727^{* *}$ & $.0729^{* *}$ & $.0384^{* *}$ & $.0361^{* *}$ \\
& $(.00605)$ & $(.00610)$ & $(.00609)$ & $(.00716)$ & $(.00634)$ \\
Worker Skill and Training & & & & & \\
College requirement for new officers & $.0549^{* *}$ & $.0338^{* *}$ & $.0308^{*}$ & $.0470^{* *}$ & .0241 \\
& $(.0115)$ & $(.0129)$ & $(.0122)$ & $(.0129)$ & $(.0125)$ \\
Hours of training for new officers & $230^{* *}$ & $201^{* *}$ & $203^{* *}$ & $143^{* *}$ & $102^{* *}$ \\
& $(12.0)$ & $(14.2)$ & $(14.1)$ & $(15.7)$ & $(14.2)$ \\
\hline \hline Include year fixed effects? & Yes & Yes & Yes & Yes & Yes \\
Include agency fixed effects? & No & Yes & Yes & Yes & Yes \\
Include state trends? & No & No & Yes & No & No \\
Include computer index trends? & No & No & No & Yes & No \\
Include initial level trends? & No & No & No & No & Yes \\
\hline
\end{tabular}

Note: This table reports regressions of measures of organizational structure on a computerization index. Each table entry represents a coefficient estimate from a separate regression where "Dependent Variable" is the left-hand side variable and controls are included as specified in the bottom rows of the table. The employees regression includes indicators for deciles of total offenses interacted with the log number of offenses as additional controls. The special units, organizational levels, directives, and percentage workers regressions include indicators for deciles of number of employees interacted with the log number of employees as additional controls. The college requirements regressions include controls for the log number of agency employees as well as the per capita income and percent of residents 25 and over with educational attainment of below high school, some high school, high school, some college, associate's degrees, bachelor's degrees, and advanced degrees in each agency's geographic area. The training regressions include controls for log number of agency employees and whether new entrants are required to have college experience. Column III includes state-specific yearly trends, column IV includes indicators for initial levels of the computer index interacted with year trends, and column $\mathrm{V}$ indicators for deciles of the initial value of the dependent variable interacted with year trends as additional controls. Standard errors clustered on agency are reported in parenthesis. ${ }^{*}$ denotes significance at the two-tailed $5 \%$ level and ${ }^{* *}$ the $1 \%$ level. 
Table 3: Effects of General and Specific IT Use on Training

\begin{tabular}{l||c} 
Explanatory Variable & Estimate \\
\hline \hline PC indicator & $43^{* *}$ \\
& $(9.05)$ \\
Mobile terminal indicator & $110^{* *}$ \\
& $(14.2)$ \\
Log(Employees) & $95^{* *}$ \\
& $(3.37)$ \\
College requirement indicator & $88^{* *}$ \\
& $(15.6)$ \\
Number of departmental functions & $-15.739^{* *}$ \\
& $(2.42)$ \\
\hline \hline $\mathrm{N}$ & 7552 \\
$R^{2}$ & 0.412 \\
\hline
\end{tabular}

Note: This table reports coefficients from a regression of the total hours of training required of new recruits on indicator variables for general and specific IT and other controls. The regression includes year and state fixed effects and incorporates data from 1990-1999. Standard errors clustered on agency are reported in parenthesis. * denotes significance at the two-tailed $5 \%$ level and ** the $1 \%$ level. 
Table 4: Relationship Between IT Use and Arrests, Offenses, and Officer Injury

\begin{tabular}{l||ccccc} 
Dependent Variable & $(\mathbf{I})$ & $(\mathbf{I I})$ & $(\mathbf{I I I})$ & $(\mathbf{I V})$ & $(\mathbf{V})$ \\
\hline \hline Total crime clearance rate & .00719 & $-3.73 \mathrm{E}-4$ & -.00141 & -.00532 & $3.61 \mathrm{E}-4$ \\
& $(.00674)$ & $(.00603)$ & $(.00595)$ & $(.00683)$ & $(.00562)$ \\
Violent crime clearance rate & $-2.19 \mathrm{E}-4$ & .0109 & .0126 & -.0102 & .0181 \\
& $(.00983)$ & $(.0105)$ & $(.0103)$ & $(.0122)$ & $(.00944)$ \\
Property crime clearance rate & $.0197^{* *}$ & .00289 & .00210 & -.00194 & .00377 \\
& $(.00596)$ & $(.00519)$ & $(.00514)$ & $(.00571)$ & $(.00492)$ \\
Total crime offense rate & $.0134^{* *}$ & $.00326^{* *}$ & $.00264^{* *}$ & $9.21 \mathrm{E}-4$ & .00101 \\
& $(9.93 \mathrm{E}-4)$ & $(7.53 \mathrm{E}-4)$ & $(7.15 \mathrm{E}-4)$ & $(7.64 \mathrm{E}-4)$ & $(6.77 \mathrm{E}-4)$ \\
Violent crime offense rate & $9.87 \mathrm{E}-4^{* *}$ & $1.47 \mathrm{E}-4$ & $4.91 \mathrm{E}-5$ & $-1.70 \mathrm{E}-4$ & $-2.42 \mathrm{E}-4$ \\
& $(1.54 \mathrm{E}-4)$ & $(1.37 \mathrm{E}-4)$ & $(1.38 \mathrm{E}-4)$ & $(1.73 \mathrm{E}-4)$ & $(1.40 \mathrm{E}-4)$ \\
Property crime offense rate & $.0124^{* *}$ & $.00312^{* *}$ & $.00260^{* *}$ & .00110 & $.00134^{*}$ \\
& $(9.03 \mathrm{E}-4)$ & $(6.88 \mathrm{E}-4)$ & $(6.52 \mathrm{E}-4)$ & $(6.98 \mathrm{E}-4)$ & $(6.26 \mathrm{E}-4)$ \\
Officers assaulted & $-72.8^{* *}$ & $-50.8^{* *}$ & $-27.0^{*}$ & .845 & -11.3 \\
& $(15.9)$ & $(16.7)$ & $(11.8)$ & $(16.1)$ & $(15.2)$ \\
Officers killed & $-.0146^{*}$ & -.0143 & -.0122 & -.0116 & $-.0219^{*}$ \\
& $(.00740)$ & $(.0128)$ & $(.0124)$ & $(.0132)$ & $(.0102)$ \\
\hline \hline Include year fixed effects? & Yes & Yes & Yes & Yes & Yes \\
Include agency fixed effects? & No & Yes & Yes & Yes & Yes \\
Include state trends? & No & No & Yes & No & No \\
Include computer index trends? & No & No & No & Yes & No \\
Include initial level trends? & No & No & No & No & Yes \\
\hline
\end{tabular}

Note: This table reports regressions of the clearance rate (arrests/offenses), offense rate (offenses/population), and officer injuries reported by an agency on a computerization index. Each table entry represents a coefficient estimate from a separate regression where "Dependent Variable" is the lefthand side variable and controls are included as specified in the bottom rows of the table. Arrest and offending figures represent index crimes. All regressions include the percent Black, percent Hispanic, and per capita income of the area covered by the agency as additional controls. The arrest regressions also control for state fixed effects and agency size deciles interacted with log number of agency employees. The offense regressions include indicators for deciles of resident population interacted with log population, $\log$ agency employees, and state fixed effects as additional controls. The assaults and officers killed regressions also include controls log violent and property arrests, log population, and log employees. Column III includes state-specific yearly trends, column IV includes indicators for initial levels of the computer index interacted with year trends, and column $\mathrm{V}$ indicators for deciles of the initial value of the dependent variable interacted with year trends as additional controls. Standard errors clustered on agency are reported in parenthesis. ${ }^{*}$ denotes significance at the two-tailed $5 \%$ level and ${ }^{* *}$ the $1 \%$ level. 
Table 5: Specifications With Leads and Lags of the Computer Index

\begin{tabular}{|c|c|c|c|c|}
\hline \multirow[b]{2}{*}{ Dependent Variable } & \multicolumn{2}{|c|}{ Lead Specification } & \multicolumn{2}{|c|}{ Lag Specification } \\
\hline & $\begin{array}{l}\text { Computer } \\
\text { Index }\end{array}$ & $\begin{array}{l}\text { Lead of } \\
\text { Index }\end{array}$ & $\begin{array}{l}\text { Computer } \\
\text { Index }\end{array}$ & $\begin{array}{l}\text { Lag of } \\
\text { Index }\end{array}$ \\
\hline \multicolumn{5}{|l|}{ "Departmental Size and Complexity } \\
\hline Number of employees & $.0681^{* *}$ & .0217 & $.0406^{* *}$ & $.0238 \dagger$ \\
\hline Number of special units & $.425^{*}$ & -.0162 & $.499 * *$ & $.442^{* *}$ \\
\hline Organizational levels & .0116 & .00297 & -.0193 & -.00686 \\
\hline Total written directives & $1.40^{* *}$ & $.499^{* *}$ & $.286^{* *}$ & $6.48 \mathrm{E}-4$ \\
\hline \multicolumn{5}{|l|}{ Departmental Organization } \\
\hline$\%$ officers with arrest powers & .00187 & .00642 & .00136 & -.00632 \\
\hline$\%$ field operations staff & -.00367 & -.00339 & -.00862 & .0113 \\
\hline$\%$ technical support staff & $.0572^{* *}$ & $.0133 \dagger$ & .0107 & -.00181 \\
\hline \multicolumn{5}{|l|}{ Worker Skill and Training } \\
\hline College requirement for new officers & .0317 & -.0164 & .00785 & -.00380 \\
\hline Hours of training for new officers & $197 * *$ & -24.2 & $58.8^{*}$ & 16.8 \\
\hline \multicolumn{5}{|l|}{ Arrests, Offenses, and Officer Injury } \\
\hline Total crime clearance rate & -.0136 & $-9.20 \mathrm{E}-4$ & .00140 & .00151 \\
\hline Violent crime clearance rate & .00574 & $.0267 \dagger$ & -.00960 & -.0197 \\
\hline Property crime clearance rate & -.00921 & -.00188 & .00140 & .00138 \\
\hline Total offending rate & $.00414^{* *}$ & $.00230^{*}$ & $.00182 \dagger$ & .00123 \\
\hline Violent offending rate & $-9.70 \mathrm{E}-5$ & $1.28 \mathrm{E}-6$ & $1.30 \mathrm{E}-4$ & $2.74 \mathrm{E}-4 \dagger$ \\
\hline Property offending rate & $.00424^{* *}$ & $.00229^{*}$ & $.00169 \dagger$ & $9.57 \mathrm{E}-4$ \\
\hline Officers assaulted & -33.1 & -25.8 & -15.8 & $-39.5 \dagger$ \\
\hline Officers killed & -.0251 & -.0123 & -.0139 & .0156 \\
\hline
\end{tabular}

Note: This table replicates the regressions from Column IV of Tables 2 and Table 4 including leads or lags in the computer index as additional explanatory variables. Within a specification, each row reports coefficient estimates from a separate regression. The first specification includes one additional lead of the index and the second specification a single additional lag. $\dagger$ denotes significance at the two-tailed $10 \%$ level, * the $5 \%$ level, and ${ }^{* *}$ the $1 \%$ level. 
Table 6: Additional Specifications

\begin{tabular}{|c|c|c|c|c|c|c|c|c|}
\hline Dependent Variable & $\begin{array}{c}(\mathrm{I}) \\
\text { Size } \\
\text { Interaction }\end{array}$ & $\begin{array}{c}(\mathrm{II}) \\
\text { Small } \\
\text { Agencies }\end{array}$ & $\begin{array}{c}\text { (III) } \\
\text { Large } \\
\text { Agencies }\end{array}$ & $\begin{array}{l}\quad(\mathrm{IV}) \\
\text { Population } \\
\text { Interaction }\end{array}$ & $\begin{array}{c}\text { (V) } \\
\text { Shrinking }\end{array}$ & $\begin{array}{c}(\mathrm{VI}) \\
\text { Low } \\
\text { Growth }\end{array}$ & $\begin{array}{c}\text { (VII) } \\
\text { Mid-Size }\end{array}$ & $\begin{array}{c}\text { (VIII) } \\
\text { Budget } \\
\text { Controls }\end{array}$ \\
\hline \multicolumn{9}{|l|}{$\overline{~ D e p a r t m e n t a l ~ S i z e ~ a n d ~ C o m p l e x i t y ~}$} \\
\hline Number of emplovees & $.0315^{* *}$ & $.0511^{*}$ & $.101 * *$ & $.0968^{* *}$ & $.0562^{* *}$ & $.0683^{* *}$ & $.111^{* *}$ & $.0995^{* *}$ \\
\hline Number of special units & $.440^{* *}$ & $\mathrm{~N} / \mathrm{A}$ & $.441^{* *}$ & $.405^{* *}$ & .564 & $.668^{*}$ & .200 & .184 \\
\hline Organizational levels & .00178 & -.00425 & -.00222 & -.00355 & .0510 & .0153 & .0247 & $.0336 \dagger$ \\
\hline Total written directives & $.825^{* *}$ & $.848^{* *}$ & $1.73^{* *}$ & $1.29^{* *}$ & $1.56^{* *}$ & $1.37^{* *}$ & $1.18^{* *}$ & $2.62^{* *}$ \\
\hline \multicolumn{9}{|l|}{ Departmental Organization } \\
\hline$\%$ officers with arrest powers & .00801 & -.00157 & $.0129^{*}$ & $.0101^{*}$ & $-7.04 \mathrm{E}-5$ & -.00384 & -.00930 & -.00180 \\
\hline$\%$ field operations staff & -.00852 & $\mathrm{~N} / \mathrm{A}$ & -.00734 & -.00955 & -.0135 & -.0193 & -.00362 & -.0107 \\
\hline$\%$ technical support staff & $.0367^{* *}$ & $\mathrm{~N} / \mathrm{A}$ & $.0592^{* *}$ & $.0540^{* *}$ & $.0858^{* *}$ & $.0849^{* *}$ & $.0500^{*}$ & $.0631^{* *}$ \\
\hline \multicolumn{9}{|l|}{ Worker Skill and Training } \\
\hline College requirement for new officers & $.0246 \dagger$ & $.0507^{* *}$ & .0280 & $.0318^{*}$ & .0242 & .0246 & $3.31 \mathrm{E}-5$ & $.0648^{* *}$ \\
\hline $\begin{array}{l}\text { Hours of training for new officers } \\
\text { Arrests, Offenses, and Officer Iniury }\end{array}$ & \multicolumn{7}{|c|}{ Arrests, Offenses, and Officer Injury } & $316^{* *}$ \\
\hline Total crime clearance rate & .00162 & .00737 & .00315 & -.00125 & $-8.47 \mathrm{E}-4$ & -.0105 & $4.95 \mathrm{E}-4$ & -.0111 \\
\hline Violent crime clearance rate & .00297 & -.0184 & .0104 & .00833 & .0129 & .00798 & .0124 & .00814 \\
\hline Property crime clearance rate & .00367 & .0134 & .00489 & .00345 & .0104 & -.00656 & .00595 & $4.27 \mathrm{E}-4$ \\
\hline Total offending rate & $7.00 \mathrm{E}-4$ & -.00179 & $.00274^{*}$ & $.00225^{* *}$ & $.00316 \dagger$ & $.00310^{* *}$ & $.00792^{* *}$ & $.00591^{* *}$ \\
\hline Violent offending rate & $-2.16 \mathrm{E}-4$ & $1.17 \mathrm{E}-4$ & $3.97 \mathrm{E}-5$ & $-1.03 \mathrm{E}-4$ & $2.00 \mathrm{E}-4$ & $3.17 \mathrm{E}-4 \dagger$ & $.00110^{* *}$ & $4.37 \mathrm{E}-4 \dagger$ \\
\hline Property offending rate & $9.29 \mathrm{E}-4$ & -.00190 & $.00270^{* *}$ & $.00236^{* *}$ & $.00296^{*}$ & $.00278^{* *}$ & $.00682^{* *}$ & $.00547^{* *}$ \\
\hline Officers assaulted & -.655 & $-3.90^{*}$ & $-52.6^{*}$ & -21.3 & 11.7 & -12.9 & -.424 & -8.80 \\
\hline Officers killed & -.00810 & .0146 & -.0149 & -.00888 & $.0398 \dagger$ & -.0131 & -.00444 & -.0345 \\
\hline
\end{tabular}

Note: This table replicates the regressions from Column II of Tables 2 and Table 4 including additional controls. Each table entry reports a coefficient estimate from a separate regression. Column I includes as additional controls a full set of interactions between deciles of the agency size distribution (measured by number of employees) and year indicators. Column II includes only agencies with fewer than 25 employees and Column III with more than 100 employees. Column IV includes a full set interactions between deciles of the population size and year indicators. Column V limits the analysis to agencies with population decreases over the course of the sample, column VI to agencies with changes in population of less than $10 \%$, and column VII agencies with population between 80000 and 100000. Column VIII includes interactions between the log annual equipment budget and decile indicators for equipment budget as additional controls. An insufficient number of agencies with fewer than 25 employees reported having special units and employee function categories to permit estimation. $\dagger$ denotes significance at the two-tailed $10 \%$ level, $*$ the $5 \%$ level, and ** the $1 \%$ level. 
Table 7: Instrumental Variables Estimates of the Effect of IT Use

\begin{tabular}{|c|c|c|c|c|c|}
\hline \multirow[b]{3}{*}{ Measure } & \multicolumn{3}{|c|}{ First Stage } & \multicolumn{2}{|c|}{ Second Stage } \\
\hline & $\begin{array}{r}\text { Effect of In } \\
\text { Compu }\end{array}$ & $\begin{array}{l}\text { iments on } \\
\text { Index }\end{array}$ & & & \\
\hline & $\begin{array}{l}\text { Pct. Work } \\
\text { Computer }\end{array}$ & $\begin{array}{l}\text { Body } \\
\text { Armor }\end{array}$ & $\begin{array}{c}\text { F-Test of } \\
\text { Instruments }\end{array}$ & $\begin{array}{c}\text { Computer } \\
\text { Index on Other } \\
\text { Outcomes } \\
\end{array}$ & $\begin{array}{l}\text { Original } \\
\text { Result }\end{array}$ \\
\hline $\begin{array}{l}\text { Departmental Size and Complexity } \\
\text { Log(Number of employees) }\end{array}$ & $\begin{array}{l}.467^{*} \\
(.194)\end{array}$ & $\begin{array}{c}.0486^{* *} \\
(.0119)\end{array}$ & $\begin{array}{c}11.2 \\
{[.000]}\end{array}$ & $\begin{array}{c}.287 \\
(.152)\end{array}$ & + \\
\hline Number of special units & $\begin{array}{l}.253 \\
(.214)\end{array}$ & $\begin{array}{l}.0186 \\
(.0154)\end{array}$ & $\begin{array}{l}1.46 \\
{[.232]}\end{array}$ & $\begin{array}{c}9.85 \\
(6.37)\end{array}$ & + \\
\hline Organizational levels & $\begin{array}{l}.414^{*} \\
(.168)\end{array}$ & $\begin{array}{l}.0309 * * \\
(.00988)\end{array}$ & $\begin{array}{c}8.13 \\
{[.000]}\end{array}$ & $\begin{array}{l}.567^{*} \\
(.272)\end{array}$ & 0 \\
\hline Total written directives & $\begin{array}{l}.554^{* *} \\
(.211)\end{array}$ & $\begin{array}{c}.0223 \\
(.0125)\end{array}$ & $\begin{array}{c}5.11 \\
{[.006]}\end{array}$ & $\begin{array}{l}7.93^{* *} \\
(2.27)\end{array}$ & + \\
\hline Departmental Organization & & & & & \\
\hline$\%$ officers with arrest powers & $\begin{array}{l}.397^{*} \\
(.163)\end{array}$ & $\begin{array}{l}.0326^{* *} \\
(.00936)\end{array}$ & $\begin{array}{c}9.22 \\
{[.000]}\end{array}$ & $\begin{array}{l}-.134 \\
(.0931)\end{array}$ & 0 \\
\hline$\%$ field operations staff & $\begin{array}{l}.333 \\
(.313)\end{array}$ & $\begin{array}{l}.0125 \\
(.0198)\end{array}$ & $\begin{array}{c}0.73 \\
{[.481]}\end{array}$ & $\begin{array}{l}-.195 \\
(.325)\end{array}$ & 0 \\
\hline$\%$ technical support staff & $\begin{array}{l}.219 \\
(.347)\end{array}$ & $\begin{array}{c}.0265 \\
(.0206)\end{array}$ & $\begin{array}{c}0.99 \\
{[.370]}\end{array}$ & $\begin{array}{l}.205 \\
(.199)\end{array}$ & + \\
\hline $\begin{array}{l}\text { Worker Skill and Training } \\
\quad \text { College requirement for new officers }\end{array}$ & $\begin{array}{l}.232 \\
(.168)\end{array}$ & $\begin{array}{l}.0297^{* *} \\
(.00962)\end{array}$ & $\begin{array}{l}5.76 \\
{[.003]}\end{array}$ & $\begin{array}{l}.0672 \\
(.252)\end{array}$ & + \\
\hline
\end{tabular}


Hours of training for new officers

Arrests, Offenses, and Officer Injury

Total crime clearance rate

Violent crime clearance rate

Property crime clearance rate

Total crime offense rate

Violent crime offense rate

Property crime offense rate

\begin{tabular}{l|l}
$.411^{*}$ & $.0361^{* *}$ \\
$(.169)$ & $(.00967)$ \\
& \\
$.524^{* *}$ & $.0403^{* *}$ \\
$(.194)$ & $(.0118)$ \\
$.516^{* *}$ & $.0407^{* *}$ \\
$(.199)$ & $(.0126)$ \\
$.517^{* *}$ & $.0415^{* *}$ \\
$(.197)$ & $(.0120)$ \\
$.548^{* *}$ & $.0414^{* *}$ \\
$(.193)$ & $(.0117)$ \\
$.548^{* *}$ & $.0413^{* *}$ \\
$(.193)$ & $(.0117)$ \\
$.549^{* *}$ & $.0414^{* *}$ \\
$(.193)$ & $(.0117)$ \\
$.620^{*}$ & $.0861^{* *}$ \\
$(.262)$ & $(.0187)$ \\
$.620^{*}$ & $.0861^{* *}$ \\
$(.262)$ & $(.0187)$
\end{tabular}

10.2
$[.000]$
9.32
$[.000]$
8.42
$[.000]$
9.28
$[.000]$
10.24
$[.000]$
10.22
$[.000]$
10.26
$[.000]$
13.13
$[.000]$
13.13
$[.000]$

$\|$

$+$

Note: This table reports instrumental variables estimates of the effect of IT on organizational and outcome measures. Each table row reports coefficient estimates from a separate IV regression. In the first stage of the IV regression, the percentage of workers in the agency's state and year who used a computer at work and an indicator for agency provision were used as instruments for the computer index. The "F-Stat" column reports the F-statistic from a joint test of the null that the coefficients on these two instruments are zero; the p-value of this test is reported in square brackets. The coefficients in the "Second Stage" column report the effect of the predicted value of the computer index on the organizational or productivity measure of interest and are conceptually equivalent to the coefficients reported in Tables 2 and 4 . All regressions include year and agency fixed effects; the controls for each specification are the same as those in column II of Tables 2 and 4. Standard errors clustered on agency are reported in parenthesis. ${ }^{*}$ denotes significance at the two-tailed $5 \%$ level and ${ }^{* *}$ the $1 \%$ level. 
Table 8: Relationship Between Offenses and Specialized Types of IT

\begin{tabular}{l||ccccc}
\multicolumn{1}{l||}{ Explanatory Variable } & Total & Homicide & Rape & Larceny & $\begin{array}{c}\text { Vehicle } \\
\text { Theft }\end{array}$ \\
\hline \hline Computer record keeping & $.0977^{* *}$ & .0310 & .0476 & $.0513^{*}$ & -.0246 \\
& $(.0235)$ & $(.0321)$ & $(.0276)$ & $(.0201)$ & $(.0222)$ \\
Computer deployment & -.0494 & -.0242 & .0470 & -.0106 & -.00704 \\
& $(.0286)$ & $(.0348)$ & $(.0328)$ & $(.0215)$ & $(.0260)$ \\
\hline \hline $\mathrm{N}$ & 12077 & 5373 & 8294 & 11728 & 11085 \\
$R^{2}$ & 0.966 & 0.911 & 0.935 & 0.980 & 0.974 \\
\hline
\end{tabular}

Note: This table reports regressions of the log number of offenses reported by an agency on measures of computerization of record keeping and computerization of officer deployment. Each column reports results of a separate regression with the log offense measure used as dependent variable indicated at the top of the column. The computer record keeping measure is a $0-1$ indicator of whether an agency uses computers for record keeping. The deployment measure is a index ranging from 0 to 1 of the use of computers for three different deployment functions. The regressions include the percent Black, percent Hispanic, per capita income, poverty rate, log number of agency employees, and population decile indicators interacted with log population as additional controls. The regressions also include agency and year fixed effects. Standard errors clustered on agency are reported in parenthesis. ${ }^{*}$ denotes significance at the two-tailed $5 \%$ level and ** the $1 \%$ level. 
Table 9: Complementarities Between IT and Management Practices in Solving Crimes

\begin{tabular}{l||cccccc}
\multicolumn{1}{l|}{} & \multicolumn{7}{c}{ Clearance Rate For: } \\
Explanatory Indicator & \multicolumn{7}{c}{ All Crimes } & Violent & Crimes & \multicolumn{2}{c}{ Property Crimes } \\
\hline \hline Compstat & $.0195^{*}$ & $.0229^{* *}$ & $.0371^{* *}$ & $.0317^{*}$ & .0132 & .0157 \\
& $(.00823)$ & $(.00827)$ & $(.0139)$ & $(.0135)$ & $(.00804)$ & $(.00802)$ \\
Computer use & .00158 & .00965 & .0196 & .0194 & .00784 & .0146 \\
& $(.00941)$ & $(.00953)$ & $(.0166)$ & $(.0166)$ & $(.00926)$ & $(.00934)$ \\
High-skilled workers & $-5.63 \mathrm{E}-4$ & .00676 & .00150 & $1.25 \mathrm{E}-4$ & .00896 & $.0144^{*}$ \\
& $(.00642)$ & $(.00655)$ & $(.0123)$ & $(.0120)$ & $(.00632)$ & $(.00640)$ \\
Problem-solving emphasis & $-.0114^{*}$ & -.00486 & $-.0353^{* *}$ & $-.0208^{*}$ & $-.0110^{*}$ & -.00400 \\
& $(.00560)$ & $(.00559)$ & $(.0106)$ & $(.0102)$ & $(.00548)$ & $(.00543)$ \\
Geographic awareness & -.00552 & .00735 & $-.0241^{*}$ & .00663 & -.00825 & .00656 \\
& $(.00605)$ & $(.00657)$ & $(.0110)$ & $(.0112)$ & $(.00593)$ & $(.00645)$ \\
Evaluation & -.00477 & -.00319 & -.0159 & -.00529 & -.00377 & -.00110 \\
& $(.00583)$ & $(.00577)$ & $(.0110)$ & $(.0106)$ & $(.00563)$ & $(.00553)$ \\
\hline \hline $\mathrm{N}$ & 1768 & 1768 & 1765 & 1765 & 1768 & 1768 \\
$R^{2}$ & 0.005 & 0.039 & 0.015 & 0.086 & 0.006 & 0.048 \\
Include demographic controls? & No & Yes & No & Yes & No & Yes \\
\hline
\end{tabular}

Note: This table reports agency-level regressions of the 1997-2003 average clearance rate (arrest/offenses) on indicators for a Compstat system as well as individual modern police management practices. Each column entry reports coefficient estimates from a separate regression with inclusion of controls as specified in the bottom row of the table. Agencies with a Compstat system simultaneously implemented elements of all five of the listed management practices in more than half of the sample years between 1997-2003. The demographic controls are the average percent Black, percent Hispanic, per capita income, poverty rate, and log population of the area covered by the agency over 1997-2003. Heteroskedasticity-robust standard errors are reported in parenthesis. ${ }^{*}$ denotes significance at the two-tailed $5 \%$ level and ${ }^{* *}$ the $1 \%$ level. 
Table 10: Complementarities Between IT and Management Practices in Deterring Crimes

\begin{tabular}{|c|c|c|c|c|c|c|}
\hline \multirow{3}{*}{$\begin{array}{l}\text { Explanatory Indicator } \\
\text { Compstat }\end{array}$} & \multicolumn{2}{|c|}{ All Crimes } & \multicolumn{2}{|c|}{$\begin{array}{c}\text { Offense Rate For: } \\
\text { Violent Crimes }\end{array}$} & \multirow{3}{*}{$\begin{array}{c}\text { Property } \\
-.00764^{* *} \\
(.00218)\end{array}$} & \multirow{3}{*}{$\begin{array}{c}\text { Crimes } \\
-.00460^{*} \\
(.00196)\end{array}$} \\
\hline & $-.00851^{* *}$ & $-.00473^{*}$ & $-8.72 \mathrm{E}-4^{*}$ & $-1.31 \mathrm{E}-4$ & & \\
\hline & $(.00247)$ & $(.00215)$ & $(3.85 \mathrm{E}-4)$ & $(2.95 \mathrm{E}-4)$ & & \\
\hline \multirow[t]{2}{*}{ Computer use } & .00108 & $.00674^{* *}$ & $-5.05 \mathrm{E}-4$ & $4.03 \mathrm{E}-4$ & .00159 & $.00634^{* *}$ \\
\hline & $(.00206)$ & $(.00199)$ & $(3.49 \mathrm{E}-4)$ & $(2.97 \mathrm{E}-4)$ & $(.00181)$ & $(.00178)$ \\
\hline \multirow[t]{2}{*}{ High-skilled workers } & .00133 & $.00658^{* *}$ & $-5.09 \mathrm{E}-4$ & $4.08 \mathrm{E}-4^{*}$ & .00184 & $.00617^{* *}$ \\
\hline & $(.00185)$ & $(.00161)$ & $(2.88 \mathrm{E}-4)$ & $(2.08 \mathrm{E}-4)$ & $(.00164)$ & $(.00147)$ \\
\hline \multirow[t]{2}{*}{ Problem-solving emphasis } & $.00944^{* *}$ & $.00830^{* *}$ & $.00121^{* *}$ & $8.52 \mathrm{E}-4^{* *}$ & $.00823^{* *}$ & $.00745^{* *}$ \\
\hline & $(.00181)$ & $(.00160)$ & $(2.74 \mathrm{E}-4)$ & $(2.10 \mathrm{E}-4)$ & $(.00160)$ & $(.00145)$ \\
\hline \multirow[t]{2}{*}{ Geographic awareness } & $.00455^{* *}$ & .00216 & $.00108^{* *}$ & $1.70 \mathrm{E}-4$ & $.00348^{*}$ & .00199 \\
\hline & $(.00158)$ & $(.00148)$ & $(2.45 \mathrm{E}-4)$ & $(2.06 \mathrm{E}-4)$ & $(.00140)$ & $(.00134)$ \\
\hline \multirow[t]{2}{*}{ Evaluation } & $.00734^{* *}$ & $.00463^{* *}$ & $8.65 \mathrm{E}-4^{* *}$ & $2.30 \mathrm{E}-4$ & $.00647^{* *}$ & $.00440^{* *}$ \\
\hline & $(.00176)$ & $(.00150)$ & $(2.82 \mathrm{E}-4)$ & $(2.06 \mathrm{E}-4)$ & $(.00154)$ & $(.00136)$ \\
\hline $\mathrm{N}$ & 1768 & 1768 & 1768 & 1768 & 1768 & 1768 \\
\hline$R^{2}$ & 0.057 & 0.253 & 0.046 & 0.402 & 0.055 & 0.216 \\
\hline Include demographic controls? & No & Yes & No & Yes & No & Yes \\
\hline
\end{tabular}

Note: This table reports agency-level regressions of the 1997-2003 average offense rate (offenses/population) on indicators for a Compstat system as well as individual modern police management practices. Each column entry reports coefficient estimates from a separate regression with inclusion of controls as specified in the bottom row of the table. Agencies with a Compstat system simultaneously implemented elements of all five of the listed management practices in more than half of the sample years between 1997-2003. The controls are the average percent Black, percent Hispanic, per capita income, poverty rate, and log number of agency employees over 1997-2003. Heteroskedasticity-robust standard errors are reported in parenthesis. ${ }^{*}$ denotes significance at the two-tailed $5 \%$ level and ${ }^{* *}$ the $1 \%$ level. 
Figure 1: Trends in Technology Use By Police Agencies
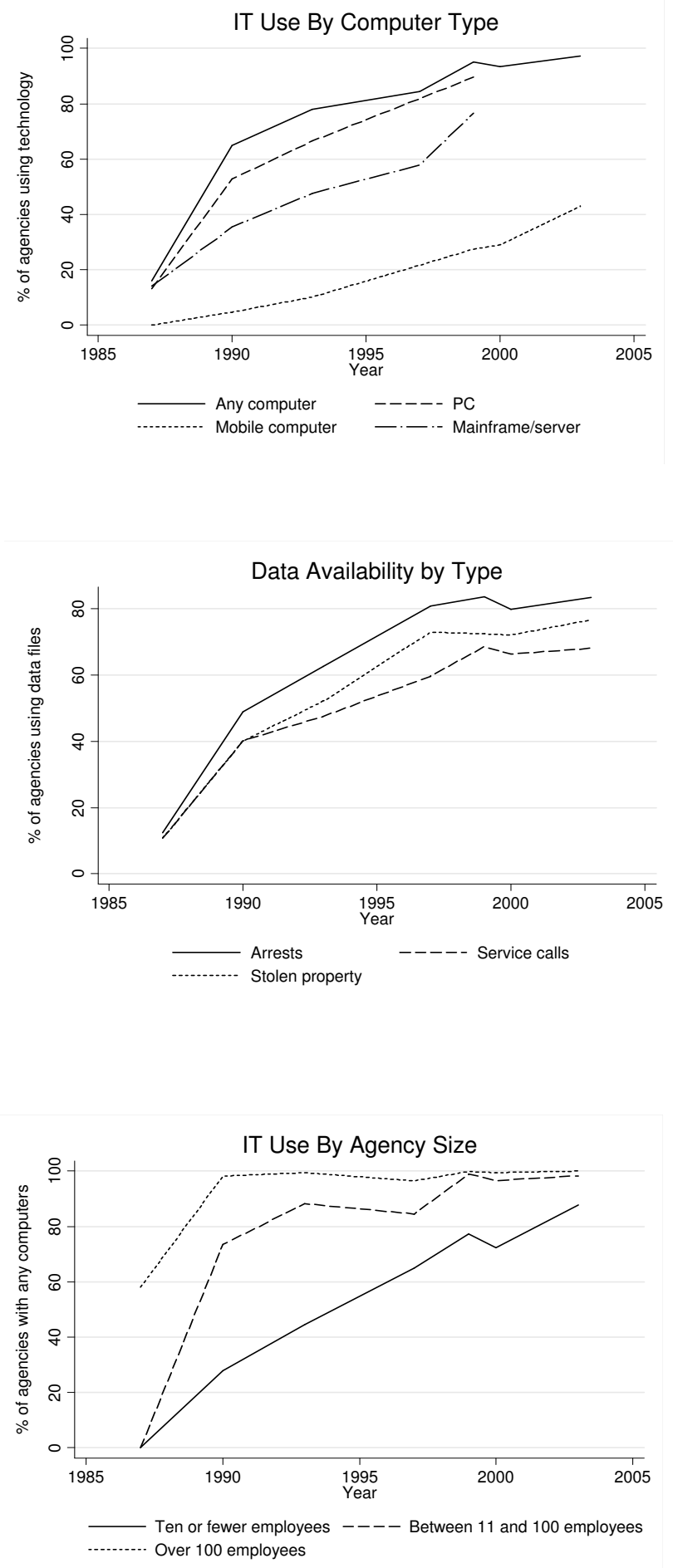


\section{Appendix}

\section{Construction of Management Practices Measures}

To examine the role of complementarities in crime reduction, we require separate agency-level measures of computerization along with relevant modern police management practices. Following Weisburd, Mastrofski, McNally, Greenspan, and Willis (2003), we identify five components of a Compstat system: 1) information technology for crime data collection and analysis 2) use of skilled officers 3) a problem-solving paradigm 4) feedback-based evaluation and 5) a geographic-based deployment structure. We code individual survey items 0-1 (No/Yes) to construct each of the five practice measures. The constituent survey questions corresponding to each practice measure are:

1. Information Technology (3)

- Does the department use computers for crime analysis?

- Does the department use computers for crime mapping?

- Does the department use computers for investigation?

- Does the department maintain computerized data on criminal histories?

- Does the department maintain computerized data on crime incidents?

- Does the department maintain computerized data on stolen property?

2. Skilled Officers (1)

- Are more than 6 months (1040 hours) of training provided for new officers?

- Are new officers required to have previous college experience?

3. Problem Solving (1.5)

- Are officers encouraged to use SARA-type problem solving?

- Are collaborative problem solving criteria used in officer evaluations?

- Does the agency engage in problem solving projects with community groups or government agencies?

4. Feedback-Based Evaluation (1)

- Is citizen survey information collected and provided to patrol officers?

- Is citizen survey information collected and used for allocating resources?

- Is citizen survey information collected and used for prioritizing crime/disorder problems?

- Is citizen survey information collected and used for redistricting patrol areas? 
5. Geographic Deployment (1)

- Are officers assigned to geographic areas?

- Are detectives assigned cases based on geographic areas?

The numbers in parenthesis above correspond to the average number of annual survey questions that must be answered positively in order for an agency to be classified as employing a particular management practice. For example, an agency which answered yes to 2 of the problem-solving questions in 1997 and 1999, 1 in 2000, and 3 in 2003 would have an average problem-solving response of $2 \geq 1.5$, so its problem-solving practice indicator would be coded as 1 . We consider a department as having a Compstat system in a given year if it answered yes to at least one of the constituent survey items for each of the five practices in a given year. Compstat agencies were agencies with Compstat systems in at least half of the available survey years. Of the 1768 agencies in our pooled sample, $11.4 \%$ used Compstat, $85.6 \%$ information technology for crime analysis, $13.8 \%$ high-skill officers, $38.5 \%$ problem-solving practices, $63.6 \%$ geographic deployment, and $41.3 \%$ feedback-based evaluation. 
Table A-1: Alternative Samples and Specifications

\begin{tabular}{|c|c|c|c|c|c|}
\hline Measure & $\begin{array}{c}(\mathrm{I}) \\
\text { Crime } \\
\text { Analysis }\end{array}$ & $\begin{array}{c}\text { Alternat } \\
\text { (II) } \\
\text { Any } \\
\text { Computer }\end{array}$ & $\begin{array}{c}\text { Specifif } \\
\text { (III) } \\
\text { Better } \\
\text { Panel }\end{array}$ & $\begin{array}{c}\text { ation } \\
\text { (IV) } \\
\text { Omit } \\
1987\end{array}$ & $\begin{array}{l}(\mathrm{V}) \\
\text { Always } \\
\text { Had IT }\end{array}$ \\
\hline \multicolumn{6}{|l|}{ Departmental Size and Complexity } \\
\hline Log(Number of employees) & $.0236^{* *}$ & $.0706^{* *}$ & $.0811^{* *}$ & $.0664^{* *}$ & $.0558^{* *}$ \\
\hline Number of special units & $.224^{* *}$ & -.126 & $.430^{* *}$ & $.525^{* *}$ & $.562 * *$ \\
\hline Organizational levels & .00259 & $.0507^{* *}$ & $.0328^{*}$ & .0153 & -.0153 \\
\hline Total written directives & $.524^{* *}$ & $2.47^{* *}$ & $1.81^{* *}$ & $.430^{* *}$ & $.342^{* *}$ \\
\hline \multicolumn{6}{|l|}{ Departmental Organization } \\
\hline$\%$ officers with arrest powers & $8.83 \mathrm{E}-4$ & $.0114^{*}$ & $.0109 \dagger$ & .00747 & $1.12 \mathrm{E}-4$ \\
\hline$\%$ field operations staff & .00246 & -.0212 & -.00744 & -.00435 & -.00427 \\
\hline$\%$ technical support staff & $.0321^{* *}$ & $.120^{* *}$ & $.0745^{* *}$ & .00129 & .00205 \\
\hline \multicolumn{6}{|l|}{ Worker Skill and Training } \\
\hline College requirement for new officers & $.0225^{* *}$ & $.0193 \dagger$ & .0258 & .00297 & 0179 \\
\hline Hours of training for new officers & $67.5^{* *}$ & $216^{* *}$ & $205^{* *}$ & $40.8^{*}$ & $60.9^{* *}$ \\
\hline \multicolumn{6}{|l|}{ Arrests, Offenses, and Officer Injury } \\
\hline Total crime clearance rate & -.00116 & -.00210 & -.00337 & -.00698 & -.00202 \\
\hline Violent crime clearance rate & $-.00982 \dagger$ & $.0223 \dagger$ & .00806 & -.00523 & .0126 \\
\hline Property crime clearance rate & $9.60 \mathrm{E}-4$ & .00223 & $-7.05 \mathrm{E}-4$ & -.00126 & $-3.31 \mathrm{E}-4$ \\
\hline Total offenses rate & $.00103^{* *}$ & $.00484^{* *}$ & $.00374^{* *}$ & $.00286^{* *}$ & .00124 \\
\hline Violent offense rate & $1.74 \mathrm{E}-4^{*}$ & $4.71 \mathrm{E}-4^{* *}$ & $7.93 \mathrm{E}-5$ & $-5.55 \mathrm{E}-5$ & $-1.21 \mathrm{E}-4$ \\
\hline Property offense rate & $8.58 \mathrm{E}-4^{*}$ & $.00435^{* *}$ & $.00366^{* *}$ & $.00292^{* *}$ & .00137 \\
\hline Assaults on officers & $-15.5^{*}$ & $-92.9^{* *}$ & $-54.9^{* *}$ & -15.1 & -12.3 \\
\hline Officers killed & -.00191 & -.0242 & -.0131 & -.00674 & -.00940 \\
\hline
\end{tabular}

Note: This table reports robustness checks of the estimated effect of IT use on organizational and arrest outcomes. Each table entry reports the results of a separate regression. The controls are the same as those reported for column IV of Tables 2 and 4 . Specifications I and II respectively replace the computer index with an indicator for computerized crime analysis and an indicator for use of any computing technology. Specification III limits the sample to agencies with available data in 4 or more years. Specification IV omits observations from 1987. Specification V limits the sample to agencies with a non-zero computer index in their earliest year of reporting. Each table entry reports a coefficient estimate from a separate regression. Standard errors clustered on agency are reported in parentheses. ${ }^{*}$ denotes significance at the two-tailed $5 \%$ level and ${ }^{* *}$ the $1 \%$ level. 
Table A-2: Initial Litigation and IT Use

\begin{tabular}{|c|c|c|c|}
\hline Group & $\begin{array}{c}\text { Avg. Litigation } \\
\text { Cases Per } 100 \\
\text { Employees }\end{array}$ & (I) & (II) \\
\hline 0-10 percentile & .435 & $\begin{array}{c}.0129 \\
(.0563)\end{array}$ & $\begin{array}{l}-.0312 \\
(.0584)\end{array}$ \\
\hline $10-20$ percentile & .964 & $\begin{array}{l}-.0682 \\
(.0685)\end{array}$ & $\begin{array}{l}-.0532 \\
(.0665)\end{array}$ \\
\hline 20-30 percentile & 1.35 & $\begin{array}{l}-.0831 \\
(.0577)\end{array}$ & $\begin{array}{l}-.0986 \\
(.0576)\end{array}$ \\
\hline 30-40 percentile & 1.73 & $\begin{array}{l}-.138^{*} \\
(.0611)\end{array}$ & $\begin{array}{c}-.174^{* *} \\
(.0615)\end{array}$ \\
\hline 40-50 percentile & 2.11 & $\begin{array}{l}-.0473 \\
(.0590)\end{array}$ & $\begin{array}{l}-.0789 \\
(.0597)\end{array}$ \\
\hline 50-60 percentile & 2.58 & $\begin{array}{l}-.0293 \\
(.0536)\end{array}$ & $\begin{array}{l}-.0499 \\
(.0544)\end{array}$ \\
\hline $60-70$ percentile & 3.42 & $\begin{array}{l}-.0698 \\
(.0636)\end{array}$ & $\begin{array}{c}-.115 \\
(.0638)\end{array}$ \\
\hline 70-80 percentile & 4.60 & $\begin{array}{l}-.0545 \\
(.0654)\end{array}$ & $\begin{array}{l}-.0727 \\
(.0643)\end{array}$ \\
\hline 80-90 percentile & 6.69 & $\begin{array}{l}-.0844 \\
(.0523)\end{array}$ & $\begin{array}{l}-.128^{*} \\
(.0526)\end{array}$ \\
\hline 90-100 percentile & 15.3 & $\begin{array}{c}.0152 \\
(.0529) \\
\end{array}$ & $\begin{array}{c}-2.15 \mathrm{E}-6 \\
(.0542)\end{array}$ \\
\hline $\begin{array}{l}\mathrm{N} \\
R^{2}\end{array}$ & & $\begin{array}{c}709 \\
0.025\end{array}$ & $\begin{array}{c}2278 \\
0.659\end{array}$ \\
\hline
\end{tabular}

Note: This table reports regressions of the final level of the IT index on indicators for deciles for the amount of litigation experienced by an agency in 1987. Each column reports coefficient estimates from a separate regression. Coefficients are measured relative to agencies with no reported litigation cases in 1987. Specification I limits the analysis to agencies for which IT data was available in 1999 while specification II includes all agencies with at least one observation on IT after 1987. Both regressions include the initial level of the computer index as a control and specification II includes indicators for the final year in which IT data was available as additional controls. Heteroskedasticity-robust standard errors are reported in parentheses. ${ }^{*}$ denotes significance at the two-tailed $5 \%$ level and $* *$ the $1 \%$ level. 


\title{
CENTRE FOR ECONOMIC PERFORMANCE Recent Discussion Papers
}

\author{
825 Laura Alfaro \\ Andrew Charlton \\ 824 Miklós Koren \\ Silvana Tenreyro \\ 823 Régis Barnichon \\ 822 Carlos Thomas \\ 821 Giulia Faggio \\ Kjell G. Salvanes \\ John Van Reenen \\ 820 Luis Araujo \\ Emanuel Ornelas \\ 819 Régis Barnichon \\ 818 Rachel Griffith \\ Sokbae Lee \\ John Van Reenen \\ 817 Tsutomu Miyagawa \\ YoungGak Kim \\ 816 Andreas Georgiadis \\ Alan Manning \\ 815 Guy Michaels \\ Xiaojia Zhi \\ 814 Ralph Ossa \\ 813 Karsten Kohn \\ Alexander C. Lembcke \\ 812 Yannis M. Ioannides \\ Henry G. Overman \\ Esteban Rossi-Hansberg \\ Kurt Schmidheiny \\ 811 Guy Michaels \\ 810 Maia Güell \\ Jose V. Rodriguez Mora \\ Intra-Industry Foreign Direct Investment \\ Technological Diversification \\ The Shimer Puzzle and the Correct Identification \\ of Productivity Shocks \\ Search Frictions, Real Rigidities and Inflation \\ Dynamics \\ The Evolution of Inequality in Productivity and \\ Wages: Panel Data Evidence \\ Trust-Based Trade \\ Productivity, Aggregate Demand and \\ Unemployment Fluctuations \\ Is Distance Dying at Last? Falling Home Bias in \\ Fixed Effects Models of Patent Citations \\ Measuring Organization Capital in Japan: An \\ Empirical Assessment Using Firm-Level Data \\ Spend It Like Beckham? Inequality and \\ Redistribution in the UK, 1983-2004 \\ Freedom Fries \\ Trade Liberalization, Outsourcing, and Firm \\ Productivity \\ Wage Distributions by Bargaining Regime: Linked \\ Employer-Employee Data Evidence from Germany \\ The Effect of Information and Communication \\ Technologies on Urban Structure \\ The Division of Labor, Coordination, and the \\ Demand for Information Processing \\ Intergenerational Mobility and the Informative \\ Content of Surnames
} Chris Telmer 
809 Stephen J. Redding Daniel M. Sturm

Nikolaus Wolf

808 Anna Lipinska

807 Eran Yashiv

806 Ghazala Azmat

Alan Manning

John Van Reenen

805 Henry G. Overman

Patricia Rice

Anthony J. Venables

804 Benjamin Aleman-Castilla

803 Eran Yashiv

802 Nicholas Oulton

801 Mirabelle Muûls Mauro Pisu

800 Richard E. Baldwin Frédéric Robert-Nicoud

799 Alejandro Cuñat Marc J. Melitz

798 Giulia Faggio

797 Nicholas Oulton

796 David Marsden Richard Belfield Salima Benhamou

795 Andrew B. Bernard J. Bradford Jensen Stephen Redding Peter K. Schott
History and Industry Location: Evidence from German Airports

The Maastricht Convergence Criteria and Optimal Monetary Policy for the EMU Accession Countries

The Beveridge Curve

Privatization, Entry Regulation and the Decline of Labor's Share of GDP: A Cross-Country Analysis of the Network Industries

Economic Linkages Across Space

The Returns to Temporary Migration to the United States: Evidence from the Mexican Urban Employment Survey

Labor Search and Matching in Macroeconomics

Jeremy Greenwood and Per Krusell, "Growth Accounting with Investment-Specific Technological Progress: A Discussion of Two Approaches” A Rejoinder

Imports and Exports at the Level of the Firm: Evidence from Belgium

Protection for Sale Made Easy

Volatility, Labor Market Flexibility, and the Pattern of Comparative Advantage

Job Destruction, Job Creation and Unemployment in Transition Countries: What Can We Learn?

Chain Indices of the Cost of Living and the PathDependence Problem: an Empirical Solution

Inventive Pay Systems and the Management of Human Resources in France and Great Britain

Firms in International Trade

The Centre for Economic Performance Publications Unit Tel 02079557673 Fax 02079557595 Email info@cep.lse.ac.uk Web site http://cep.lse.ac.uk 